IZA DP No. 8253

The Consequences of Increased Enforcement of Legal Minimum Wages in a Developing Country: An Evaluation of the Impact of the Campaña Nacional de Salarios Mínimos in Costa Rica

T. H. Gindling

Nadwa Mossaad

Juan Diego Trejos

June 2014 


\title{
The Consequences of Increased Enforcement of Legal Minimum Wages in a Developing Country: An Evaluation of the Impact of the Campaña Nacional de Salarios Mínimos in Costa Rica
}

\author{
T. H. Gindling \\ $U M B C$ and IZA
}

Nadwa Mossaad

$U M B C$

Juan Diego Trejos

Universidad de Costa Rica

\author{
Discussion Paper No. 8253 \\ June 2014 \\ IZA \\ P.O. Box 7240 \\ 53072 Bonn \\ Germany \\ Phone: +49-228-3894-0 \\ Fax: +49-228-3894-180 \\ E-mail: iza@iza.org
}

Any opinions expressed here are those of the author(s) and not those of IZA. Research published in this series may include views on policy, but the institute itself takes no institutional policy positions. The IZA research network is committed to the IZA Guiding Principles of Research Integrity.

The Institute for the Study of Labor (IZA) in Bonn is a local and virtual international research center and a place of communication between science, politics and business. IZA is an independent nonprofit organization supported by Deutsche Post Foundation. The center is associated with the University of Bonn and offers a stimulating research environment through its international network, workshops and conferences, data service, project support, research visits and doctoral program. IZA engages in (i) original and internationally competitive research in all fields of labor economics, (ii) development of policy concepts, and (iii) dissemination of research results and concepts to the interested public.

IZA Discussion Papers often represent preliminary work and are circulated to encourage discussion. Citation of such a paper should account for its provisional character. A revised version may be available directly from the author. 


\section{ABSTRACT \\ The Consequences of Increased Enforcement of Legal Minimum Wages in a Developing Country: An Evaluation of the Impact of the Campaña Nacional de Salarios Mínimos in Costa Rica}

In August 2010 the Costa Rican government implemented a comprehensive program to increase compliance with legal minimum wages, the Campaign for Minimum Wages. To evaluate the impact of the Campaign, we use a regression discontinuity approach, which compares what happened to workers who before the campaign had been earning below the minimum wage to those who before the Campaign had been earning above the minimum wage. We analyze a panel data set with information on workers from before the Campaign began (July 2010) and after the Campaign had been in operation for some time (July 2011). We find evidence that the Campaign led to an increase in compliance with minimum wage laws in Costa Rica; the mean earnings of those earning less than the minimum wage in 2010 increased by approximately $10 \%$ more than the earnings of those who had been earning more than the minimum wage. The Campaign led to the largest increases in the wages of women, younger workers and less-educated workers. We find no evidence that the Campaign had a negative impact on the employment of full-time workers whose wages were increased. We find some weak evidence that the Campaign had a negative impact on the employment of part-time private sector employees. Although increased inspections were mainly targeting minimum wage violations, we also observe an increase in compliance with a broader set of labor standards and a positive spillover effect relative to other violations of labor laws.

JEL Classification: J3, J33, J38, 017, 053

Keywords: minimum wages, labor code enforcement, Latin America, employment, wages

Corresponding author:

T. H. Gindling

University of Maryland Baltimore County

1000 Hilltop Circle

Baltimore, MD 21250

USA

E-mail: gindling@umbc.edu 


\section{The Consequences of Increased Enforcement of Legal Minimum Wages in a Developing Country: An Evaluation of the Impact of the Campaña Nacional de Salarios Mínimos in Costa Rica ${ }^{1}$}

\section{Introduction}

Non-compliance with labor protection legislation such as the legal minimum wage is widespread in many developing economies. Almost all recent studies of legal minimum wages in developing countries have found a high degree of non-compliance (for example, see Lemos, 2004; Harrison and Scorse, 2004; Strobl and Walsh, 2001; and Cunningham, 2007). Costa Rica is no exception; previous studies have found that over $30 \%$ of workers legally covered by minimum wage legislation in Costa Rica actually earn less than the legal minimum (Gindling and Trejos, 2010; Gindling and Terrell, 1995, 2005 and 2007).

Despite the prevalence and importance of non-compliance with minimum wage legislation, there have been relatively few empirical studies of the impact of non-compliance on labor market outcomes in developing economies. In this paper, we contribute to this sparse literature by evaluating the impact of a comprehensive program designed by the Costa Rican Ministry of Labor to increase compliance with minimum wage legislation. The National Campaign for Minimum Wages began in August 2010 with a well-funded publicity campaign to "create a level of consciousness among employers and workers regarding the importance of complying with the minimum wage." The Campaign encouraged workers to denounce employers who pay less than the minimum wage and increased labor inspections targeting minimum wage violations. This is the first time that a Latin American government has implemented such a comprehensive plan to

\footnotetext{
${ }^{1}$ Funding for this research was provided by the Canadian International Development Research Center (IDRC) through a grant to the Instituto de Investigaciónes en Ciencias Económicas of the University of Costa Rica (grant number 10620-002). Luis Oviedo provided valuable research assistance. We are grateful for helpful comments and advice from: Haroon Borat, Dennis Coates, Ravi Kanbur, Marvin Mandell, Dave Marcotte, Michael Piore, Edgard Rodriquez, Jeffrey Smith, David Weil and other participants at the IDRC-Cornell Workshop on Labor Standards Enforcement, a UMBC Public Policy/Economics seminar, the sixth Meetings of the LACEA Impact Evaluation Network, the IDRC Workshop on Minimum Wages: Enforcement and Impact Policy Implications of Global Experience and a Brown Bag Seminar to the Labor Team of the Human Development Network at the World Bank. We are indebted to the National Statistics and Census Institute of Costa Rica for access to, and processing of, the household survey data. Finally, we are grateful to Sandra Piszk, Costa Rican Minister of Labor, and officials of the General Directorate of Planning and the National Directorate of Inspections for their assistance, encouragement, and for responding quickly and fully to our numerous questions. Nonetheless, all errors in the paper are the responsibility of the authors.
} 
reduce non-compliance with minimum wages. As such, it provides a unique opportunity to study the impact of increased enforcement of minimum wages on compliance, wages, employment, whether employers pay into the Social Security system or provide other legally-mandated nonwage benefits.

Previous published papers have identified the impact of increased enforcement of minimum wages in developing countries by comparing regional differences in labor inspections to regional differences in compliance, informality, and other labor market outcomes. The authors of these studies point out, in the words of Ronconi (2010), "There are two main challenges to estimating the causal effect of enforcement on compliance. First, adequate measures for both variables are not easily available...A second challenge is that a potential simultaneous relation between enforcement and compliance complicates identification. On the one hand, firms' propensities to comply with regulations depend on the probability of being penalized, and, on the other hand, public enforcement agencies' resources are likely to be affected by the extent of compliance." (pp. 719-720). These two challenges are addressed in our study. First, the National Campaign for Minimum Wages provides a clear and precise break where enforcement increased substantially. Second, as we show later in this paper, the National Campaign for Minimum Wages was not an endogenous response to increased violations of minimum wage laws, but rather was a policy change that occurred because a new president and administration recognized publicly for the first time that non-compliance with minimum wage legislation is a problem in Costa Rica.

\section{Literature Review}

Basu, Chau and Kanbur (2010) develop a theoretical model where the labor market can be characterized by imperfect competition, imperfect enforcement of minimum wage laws, and imperfect commitment on the part of government inspectors. Within this framework the impact of legal minimum wages is complex. For example, Basu, Chau and Kanbur (2010) show that, depending on the degree of compliance and the structure of the labor market, higher minimum wages can result in increases, decreases or no significant changes in wages, employment or informality. They also show that the impact of greater enforcement on wages, employment and informality is ambiguous - all might increase, decrease or stay the same depending on labor market structure and labor supply and labor demand elasticities. That is, Basu, Chau and Kanbur 
(2010) show that, under different sets of reasonable assumptions, increased enforcement of legal minimum wages has ambiguous effects on labor market outcomes. Whether increased enforcement of minimum wages has a positive or negative impact on wages, employment, informality and poverty is, therefore, an empirical question. Next we review the recent empirical literature on the impact of increased enforcement of labor market protection legislation in developing economies.

Ronconi (2008) evaluates the impact of increased labor inspections in Argentina on minimum wages, maximum hours, paid vacation time, annual extra monthly wage and two components of social security: workers compensation insurance and health insurance. Ronconi constructs a province-level panel data set with annual observations for the period 1995-2003. The measure of enforcement used is the annual number of labor inspections per capita by province. Regressions are estimated where the dependent variables are measures of the level of compliance with the above labor regulations in each province and year, and the independent variables include the number of labor inspections per capita, labor market and population characteristics, and province-level fixed effects. To address the possible simultaneous relationship between noncompliance and increased enforcement, election cycles (years) are used as an instrumental variable for the number of labor inspections per capita. Ronconi (2008) finds that increased enforcement caused increased compliance with minimum wage legislation and maximum legal working hours. On the other hand, increased enforcement did not have a statistically significant impact on compliance with social security regulations, paid vacations or the annual extra monthly wage.

Almeida and Susanli (2011) use a large firm level data set across 63 countries to examine the impact of firing regulations and enforcement on firm size. They regress firm size on an interaction between measures of de jure firing costs and enforcement of labor laws. Other firm level characteristics are used as control variables. To address the issue of simultaneous causality between enforcement and non-compliance they include sector and country fixed effects. They find evidence that more stringently enforced firing regulations reduce the average number of employees per firm. Almeida and Carneiro (2009) come to a similar conclusion using firm-level data on firm characteristics and city-level enforcement of labor regulations in Brazil. To address the simultaneity between non-compliance and inspections, Almeida and Carneiro (2009) use 
distance from the firm to the nearest inspection office as an instrument for the probability of inspection (number of inspections per 100 firms). They conclude that stricter enforcement of labor regulations reduces firm size.

Almeida and Aterido (2011) use the same firm-level data set as Almeida and Susanli (2011), and a similar empirical technique, to examine the relationship between enforcement of labor regulations and on-the-job training. They find evidence that more stringently enforced labor regulations increase the probability of on-the-job training.

Almeida and Carneiro (2011) evaluate the impact of differential enforcement of labor regulations across cities in Brazil on the proportion of workers who are in the formal sector, informal sector, self-employed and non-employed, and on wages in the formal and informal sectors. The measure of enforcement used is the interaction between the distance of the city from the nearest enforcement office and the number of inspectors in that office. An increase in the value of this interaction variable indicates an increase in enforcement. Almeida and Carneiro (2011) show that this interaction variable is correlated with an increased number of inspections, but argue that it is not likely to suffer from an endogenous relationship with non-compliance. To control for the possibility of a simultaneous relationship between enforcement and non-compliance, Almeida and Carneiro (2011) include, as a control variable, the outcome variable in an earlier period when "enforcement was a less important activity" (p.3). They conclude that in cities with more enforcement of labor regulations there is more formal employment, less self-employment and less employment overall (more non-employment). They also find evidence that increased enforcement causes an increase in wages at the bottom and a decrease in wages at the top of the formal wage distribution. They argue that formal sector workers pay for more generous mandated benefits by receiving lower wages.

Harrison and Scorse (2010) use firm-level data and a difference-in-difference research design to evaluate the impact of an anti-sweatshop campaign in Indonesia. They present evidence that the anti-sweatshop campaign led to significant increases in wages for workers in firms targeted by the campaign relative to workers in firms not affected by the campaign, and that the "activism led to higher wages primarily by increasing compliance with the minimum wage" (p.269). While they find that higher minimum wage levels led to reductions in aggregate manufacturing 
employment, they find no evidence that the increased compliance with minimum wages brought about by the anti-sweatshop campaign had a significant negative impact on employment in targeted firms, although "it did lead to falling profits, reduced productivity growth, and plant closures for smaller exporters" (p. 270).

\section{The Campaña Nacional de Salarios Mínimos}

On August 9, 2010 the Campaña Nacional de Salarios Mínimos (National Campaign for Minimum Wages) was announced jointly by Costa Rican President Laura Chinchilla and Minister of Labor Sandra Piszk with much fanfare and press attention. The explicit purpose of the Campaign is to improve compliance with minimum wage legislation. There were three broad mechanisms presented to achieve this goal: (1) publicity to "create a level of consciousness among employers and workers regarding the importance of complying with the minimum wage"; (2) encourage workers to report employers who pay less than the minimum wage (to support this measure the Ministry of labor expanded a call center with a call-in complaint line: 800TRABAJO); and (3) increase in labor inspections targeting minimum wage violations. Coincident with these three mechanisms, the Ministry of Labor implemented a new computerbased information system to keep track of violations of labor laws (the Sistema Electrónico de Casos).

The Campaign was partly a response to published research that showed high levels of noncompliance with minimum wages in Costa Rica and a public campaign to confront this issue by the director of the Estado de la Nación program, Miquel Guitierrez (Arias, 2011). ${ }^{2}$ At the same time, non-compliance with labor regulations also gained visibility because of the CAFTA-DR trade negotiations. Representatives of U.S. labor interests have long argued that non-compliance with labor regulations was widespread in Central America, and this was an issue in the CAFTADR negotiations. In response to pressure from U.S. labor interests, the U.S. Labor Department financed a program titled Cumple y Gana, administered by the non-governmental FUNPADEM (Fundacion para la Paz y Democracia) with support from the International Labor Office. The Cumple y Gana program was designed to strengthen the capabilities of Central American

\footnotetext{
${ }^{2}$ Research showing high levels of non-compliance included: Gindling and Terrell, 1995, 2005 and 2007; Gindling and Trejos, 2010; Estado de la Nación (2009); and unpublished studies by the Costa Rican Ministry of Labor.
} 
governments to carry out effective labor inspections. While the Cumple y Gana program did not focus exclusively on minimum wages, improving inspections for minimum wage compliance was an important component and goal. The Cumple y Gana program assisted in the design and initial financing of the Campaign for Minimum Wages. Finally, a new Costa Rican President and Minister of Labor took office in May 2010. President Laura Chinchilla came to power, in part, on a law-and-order platform. Increased enforcement across the board of existing laws fit into this platform, and increased enforcement of minimum wage legislation played well with the working class and labor segment of her Liberación Nacional party. One interesting aspect of this background is that the campaign to increase compliance with minimum wages came into existence because of research results and politics, and not because of any clear increase in noncompliance in Costa Rica. In terms of our empirical analysis, this helps address the simultaneity/endogeneity problem that occurs in other studies that use regional variation in inspections as the strategy to identify the impact of increased enforcement (i.e. Ronconi, 2008).

The first component of the campaign, the publicity campaign, began with the joint announcement on August 9, 2010 by the Minister of Labor and the President, with both wearing t-shirts listing the 800-TRABAJO telephone number of the call center. The announcement of the initiation of the campaign appeared widely in both the national and international press. The publicity campaign, which continues today, has included announcements in the press, 1,800 prime time radio commercials, $\$ 1,500$ spent on television commercials, several web sites, over 130 billboards at bus stops and other public places, posters at work places, over 30,000 pamphlets, and widely distributed t-shirts (see figure 1). In the most public display, both teams in a semifinal match for the national professional soccer league returned to the field at half time sporting the t-shirts. ${ }^{3}$ In addition, once each month during the Campaign, the Minister of Labor has held a press conference where she has highlighted and described the increased inspections, and presented information to show that the campaign is having an effect. The press conferences have always been followed by stories in the major Costa Rican newspapers about the campaign. The press conferences keep the attention of the public on the need to reduce non-compliance and build public support for the campaign.

\footnotetext{
${ }^{3}$ There is a minimum wage for professional soccer players, and prior to the semi-final match several newspapers ran stories about some professional soccer players being paid less than the minimum wage.
} 
The campaign also incorporated workers into the process of improving compliance by greatly expanding a call center and toll-free number (800-TRABAJO ) to answer questions about labor legislation and to receive complaints (denuncias) from workers about firms violating labor regulations. Before the campaign, to register a complaint (denuncias), workers had to go in person to a regional office of the Ministry of Labor. Now, a complaint can be registered anonymously by phone, and each complaint results in an inspection by the Ministry of Labor. Between August 1, 2010 and June 30, 2011 there were 77,816 calls, resulting in 988 complaints; $768(78 \%)$ complaints were about minimum wages. In addition to complaints, the information aspect of the call center is important—workers can call to ask what their minimum wage should be, given their job, something that is not easy because of the complex structure of minimum wages in Costa Rica where the minimum wage applicable to a worker depends on her/his occupation, education and skill level.

The campaign also included an increase in inspections targeting minimum wage violations. Before discussing the way in which inspections were increased, it is necessary to describe the process of labor inspections in Costa Rica. Labor inspections begin with an initial visit by an inspector. Initial visit by an inspector can be because of a complaint (denuncia) or at the discretion of the inspector (inspectors are responsible for a geographic region). Further, inspections can be a full inspection assessing compliance with all labor code violations or focused on one or few violations. Inspectors examine payroll records, and interview workers. In small firms inspectors interview all workers, in large firms a sample of workers is interviewed. Full inspections investigate potential labor market violations including those related to minimum wages, overtime pay, payroll records (comprobante de pago), Social Security payments, Work Risk insurance payments, emergency exits and other parts of the safety code, mandated maternity leave, holidays, work week violations, aguinaldo ( $13^{\text {th }}$ month pay), etc. If an inspector determines there are violations of the labor code, a second inspection is carried out within 30 days of when the violation is recorded. Labor inspectors refer any firms still found in violation of labor market regulations to the Labor Tribunals. ${ }^{4}$ Labor inspectors cannot impose fines or sanctions; only the Labor Tribunals can do this.

\footnotetext{
${ }^{4}$ Inspections for violations of Social Security are generally carried out separately. Social Security inspectors have more resources and can impose sanctions (including fines; up to closing down a firm). If a
} 
Beginning August 2010 and continuing throughout 2011, the Ministry of Labor increased the number of inspections focused on minimum wage violations. Inspectors in these focused or targeted inspections also checked overtime pay and payroll records. Targeted (focused) inspections do not explicitly look for any other labor code violations. The increase in the number of targeted inspections was accompanied by a limited increase in the number of inspectors and resources available to the Directorate of Inspection: the budget of Directorate of Inspection increased $27 \%$ in real terms, the number of inspectors went from 90 to 101 , the fleet of cars available to inspectors went from 11 to 22 , and inspectors were given 64 new laptop computers.

In our interviews with inspectors and supervisors at the Direction of Inspections, we heard many complaints from inspectors about the lack of resources - for example, there are no maps showing the locations of firms, so that inspectors have to rely on memory in order to locate firms. In addition, resources were shifted away from full inspections in favor of targeted inspections of minimum wage violations. Some inspectors told us that it is possible that the campaign for minimum wages resulted in fewer violations of other labor regulation violations being found because of fewer full inspections. Further, inspectors were under pressure to increase the number of firms inspected for minimum wage violations, so that they spent less time per inspection (which they could do as long as they focused mainly on minimum wages) and tended to focus on regions, sectors and industries where there were many firms within small geographic areas. According to inspectors, effectively this implied fewer inspections of agricultural and rural firms; and more inspections of small firms (which took less time), especially in commerce, in urban areas (where many firms exist close together) and near the inspection offices (so that transportation time and costs were minimized). ${ }^{5}$

Social Security inspector finds a violation of any other part of the labor code they are not required to inform the Ministry of Labor. On the other hand, if a Ministry of Labor inspector finds a violation of Social Security legislation, they are required to inform the Social Security inspectors. In some cases of a full inspection there is coordination between agencies, and a joint inspection is carried out by Ministry of Labor, Social Security and Ministry of Health inspectors. However, targeted minimum wage inspections are not joint inspections.

${ }^{5}$ Several other reforms were proposed but not yet implemented, such as: to allow Ministry of Labor inspectors to levy fines for violations; an accord that requires Social Security inspectors to tell the Ministry of Labor if they find a minimum wage violation (this accord was ratified near the end of the first year of the Campaign, after July 2011); and publishing names of firms that violate minimum wage law. In fact, the Costa Rican Supreme Court ruled that the Ministry of Labor was required to publish the names 
Table 1 shows that the total number of firms inspected increased in 2010 and 2011, but that the number of full inspections fell as the number of inspections focused on minimum wages increased. The increase in targeted inspections resulted in an increase in the number of firms found to be in violation of minimum wage laws. On the other hand, as the number of full inspections fell, so did the number of firms found to be violating other (non-minimum wage) labor laws. Non-compliance with minimum wages is substantial in firms of all sizes and in all industry sectors (see table A1). Minimum wage violations found in focused inspections were most common in micro and small firms (over $40 \%$ of firms inspected were found in violation), agriculture (44\% of firms inspected were found in violation), commerce (44\%) and manufacturing $(43 \%)$.

During the first year of the Campaign (which is the period covered in this study) targeted inspections were concentrated in commerce (6,267 firms inspected, representing $11.9 \%$ of private sector employees in that sector) and manufacturing (1008 firms representing $12.5 \%$ of employees in that sector), with a smaller yet substantial number in services (inspections covered $4.3 \%$ of employees in that sector). On the other hand, there were few inspections in agriculture (460 firms representing $2.2 \%$ of workers in that sector), transportation (1.6\% of workers) or construction (2.2\% of workers). There were substantially more inspections of micro and small firms compared to medium and large firms. However, comparing the number of workers in firms that were inspected leads to the conclusion that workers in large firms were over-represented in the inspections; $9.7 \%$ of private sector employees in large firms were subject to inspections, compared to less than $6 \%$ of workers in small and micro-firms (table A1).

A high percent of firms found in violation in the first inspection were found to have complied with minimum wages by the second inspection (see table A2). This may indicate that inspections were successful. However, there were no further follow-up inspections beyond the second inspection, so it is not clear if firms remained in compliance after the second inspection. Firms found to still be in violation after the second inspection were referred to labor tribunals for possible sanctions. Labor tribunals are very slow, and while sanctions can be between 1 and 23

of firms which had violated labor regulations-but the Ministry has so far not complied, under extreme pressure from the Chamber of Commerce (which is clearly worried about the reputation of its members). In the second year of the program (after July 2011), the Ministry of Labor also introduced "virtual inspections," where the initial inspection was carried out over the internet. 
months of salary, the average fine is less than 5 months of salary (Piszk, 2011). The low sanctions imply that being discovered to have violated minimum wage legislation through a labor inspection imposes very few monetary costs on firms. It was suggested to us that the biggest cost to firms of being found in violation of minimum wage laws is in terms of their reputations with the public in general.

Figure 2 presents the evolution of the real minimum wage for unskilled workers, GDP growth rates and the unemployment rates for the year of the Campaign and several years before. This figure suggests that the Campaign was launched in a period of increases in the real minimum wage and slow economic growth. Specifically, after an economic expansion (high GDP growth and low unemployment) from 2003 to 2007, unemployment rates rose and GDP growth rates fell beginning in the second half of 2008. The economy resumed growth in 2010 and 2011, but at slower rates than in the 2003 to 2007 period, and throughout 2010 and 2011 the unemployment rate remained high. Coincident with the onset of the recessionary period, and after a long period of stagnation from 1999 to 2008, real minimum wages rose by almost $10 \%$ between 2008 and 2011.

\section{Data}

The primary methodology we use to evaluate whether the Campaña Nacional de Salarios Mínimos had an impact on compliance, wages, employment and non-wage benefits is regression discontinuity. In the regression discontinuity approach we compare workers who, prior to the Campaign, earned just below the minimum wage with workers who, prior to the Campaign, earned just above the minimum wage. If successful, the Campaign should increase the wages of those who were earning below the minimum wage but will have no impact on the wages of those who were already earning at or above the minimum wage. To conduct this analysis, we therefore need data on the wages and other personal and labor market characteristics of workers before the Campaign (which begun in August, 2010) and data on these same workers after the introduction of the campaign. That is, we need panel or longitudinal data, where we observe the same individuals before and after the campaign. 
The data we use in this analysis is a panel data set of individuals constructed from two annual Costa Rican National Household Surveys. The first survey was conducted in July 2010 (just before the campaign), the second survey was conducted in July 2011 (after the campaign had been active for some time). The National Household Surveys are conducted annually by the Costa Rican National Statistics and Census Institute and use a rotating sample design whereby interviewers in 2011 returned to approximately $75 \%$ of the households interviewed in 2010 . In both 2010 and 2011 interviewers recorded a code identifying the address of each household, as well as the name of each household member. Working with the Statistics Institute, we used this information to construct a panel data set of households (who remained at the same address between 2010 and 2011) and individuals (who remained with the same households between 2010 and 2011).

Costa Rica has a complex minimum wage system where different minimum wages apply to workers in different occupations, education and skill levels. ${ }^{6}$ Combining information on occupations and minimum wages from the Ministry of Labor with data on the occupations, skill level and education level of workers from the panel surveys, we assign each worker a minimum wage in 2010 and $2011 .^{7}$

Table 2 presents descriptive statistics of the worker-level panel data set we use in our analysis, divided between those who earn below, at and above the minimum wage. We consider only private sector employees because they are the workers who are legally covered by minimum wage legislation in Costa Rica; wages for public sector workers are set based on a different set of institutionally-determined wages, and self employed workers are not covered by minimum wage legislation because they cannot be forced to pay themselves the minimum wage. ${ }^{8}$ We limit our analysis to full-time workers (40 hours per week or more) for two reasons. First, most minimum

\footnotetext{
${ }^{6}$ The Costa Rican minimum wage decrees for 2010 and 2011 can be found at http://rmeza.jimdo.com/pensiones-alimentarias/recursos-didacticos/decretos-salarios-mínimos/ ${ }^{7}$ In 2010 and 2011 minimum wages were revised twice a year, on January 1 and July 1. The household surveys report monthly earnings for June. Minimum wages and earnings are both reported in monthly terms. To determine the workers wage relative to the minimum wage, for full-time workers we compare the June monthly earnings of workers with the January monthly minimum wage. We compare the minimum wage to the reported monthly gross wage in colones (excluding bonuses, tips and payments in kind), without any adjustments for potential under-reporting or non-response.

${ }^{8}$ Private sector employees do not include public sector workers, the self-employed, owners of firms, unpaid family workers or domestic workers.
} 
wages are specified in the government decrees as monthly earnings for full-time workers, and it is not clear how or when minimum wages apply to part-time workers. Second, because of the potential measurement error estimating part-time wages that can occur because the data report monthly earnings but weekly hours worked. To take potential measurement error into account, we look at a band of $5 \%$ around the minimum wage. That is, table 2 actually reports the proportion of workers earning below $95 \%$ of the minimum wage, from $95 \%$ to $105 \%$ of the minimum wage, and above $105 \%$ of the minimum wage.

Table 2 presents the distribution of workers earning below, at and above the minimum wage by gender, age, education, firm size and industry sector. The proportion of workers earning below the minimum wage is highest for female, younger, least educated and workers in micro-firms (less than 6 workers). Among industry sectors, the proportion of workers earning below the minimum wage is highest in agriculture, commerce and services compared to other industries. Summary statistics are also presented for all workers and for two sub-samples of the data: workers with earnings within $10 \%$ of the minimum wage, and workers within $15 \%$ of the minimum wage. The regression discontinuity design assumes that workers earning just above the minimum wage are similar to those earning just below the minimum wage in all observable and unobservable ways except for the treatment. Note that in table 2, although we see a disproportion percentage of females, youth, less educated and small firm workers earning below the minimum wage in the full sample, the concentration becomes smaller and sometimes disappears completely as we limit the sample to workers closer to the minimum wage. Nevertheless, even for the narrowest band presented, there are some differences in the characteristics of workers above and below the minimum wage. Specifically, workers in micro-firms and with the least years of education have higher concentration below the minimum compared to workers in larger firms and with more years of education. In appendix 1 we present the results of tests of the assumptions underlying the RD design.

\section{Regression Discontinuity Methodology}

RD designs are appropriate where treatment is determined by whether an observed "assignment" or "forcing" variable falls below or exceeds a known cutoff point. In our case, whether a worker receives the "treatment" (is affected by the Campaign for Minimum Wages) depends on whether 
the worker is earning less than the minimum wage prior to the Campaign (in 2010). Workers who initially earned above the minimum wage are not affected by the Campaign and therefore do not receive the treatment. $\mathrm{RD}$ designs compare outcomes for those workers who have values of the "assignment" variable just below the cutoff with those workers who are just above the cutoff. In our case, the assignment variable is the difference between the wage received by the worker in 2010 and the minimum wage that applies to that worker in 2010. The cutoff point is where this variable is equal to zero; that is, where the wage is equal to the minimum wage. If the assignment variable is below the cutoff, this indicates that the worker is earning below the minimum wage, and should be affected by the Campaign (that is, that worker is part of the treatment group). If the assignment variable is above the cutoff, this indicates that the worker will not be affected by the Campaign, and is therefore part of the control group.

The first labor market outcome we look at is the change in wages, which will indicate whether or not compliance with minimum wage legislation increased after the Campaign. To study the impact of the Campaign on wages and compliance, we compare the change in wages between 2010 and 2011 for workers earning above and below the minimum wage in 2010 (before the Campaign began). If the Campaign was effective in causing employers to pay the minimum wage to those previously earning below the minimum wage, then we should see the wages of those initially earning below the minimum wage to increase in 2011 by more than the wages of those who were earning at or above the minimum wage. This would be evidence that the Campaign increased compliance with minimum wage legislation.

One advantage of the RD design is that it can be used to illustrate the impact of the treatment graphically. Figure 3 shows how this might work. In both panels of figure 3, the wages of workers earning just below the minimum wage in 2010 increase by more than the wages of workers who had been earning just above the minimum wage. The RD estimate of the impact of the Campaign on wages is the difference in the wage change at the cutoff point. Using a nonparametric local linear regression estimation technique and data on the wages of private sector employees in 2010 and 2011, we construct figures like those in figure 3 in order to see whether there is a "jump" in the relationship at the cutoff point. Non-parametric estimation allows us to capture any possible non-linear relationship between the outcome variable (the wage change) and 
the assignment variable (the difference between the wage and minimum wage), such as that shown in panel B of figure.

We also present more formal regression discontinuity estimates of the treatment effect. Let $Y_{i}=$ the outcome (i.e. the change in wages for worker i from before to after the Campaign: $\log \mathrm{W}_{\mathrm{i}, 2011}$ $\left.-\log \mathrm{W}_{\mathrm{i}, 2010}\right)$. The gap between the reported wage and minimum wage for each worker i in 2010 (before the Campaign) is the assignment variable $\left(\log \mathrm{W}_{\mathrm{i}, 2010}-\log M \mathrm{~W}_{\mathrm{i}, 2010}\right)$. Let $\mathrm{D}_{\mathrm{i}}=1$ if worker $\mathrm{i}$ earns less than the minimum wage in 2010 , and $\mathrm{D}_{\mathrm{i}}=0$ if the worker earns more than the minimum wage in 2010. Assuming that, except for the jump at the cutoff point (where $\left.\log \mathrm{W}_{\mathrm{i}, 2010}=\log \mathrm{MW} \mathrm{W}_{\mathrm{i}, 2010}\right)$, the relationship between the assignment variable $\left(\log \mathrm{W}_{\mathrm{i}, 2010}\right.$ $\left.\log M W_{i, 2010}\right)$ and outcome variable $\left(Y_{i}\right.$, i.e. $\left.\log W_{i, 2011}-\log W_{i, 2010}\right)$ is linear, as in panel $A$ of figure 2 , a simple way to estimate the treatment effect, $\tau$, is by estimating the following linear regression (Lee and Lemieux, 2010):

$$
\mathrm{Y}_{\mathrm{i}}=\alpha_{1}+\tau \mathrm{D}_{\mathrm{i}}+\beta\left(\log \mathrm{W}_{\mathrm{i}, \mathrm{t}-1}-\operatorname{LogMW}_{\mathrm{i}, \mathrm{t}-1}\right)+\varepsilon_{\mathrm{i}}
$$

However, if the relationship is non-linear, then equation (1) will not provide a good estimate of the RD effect. One way to incorporate a non-linear relationship between the assignment variable and outcome variable is to model that relationship as a higher order polynomial. In this paper we present estimates using a very flexible functional form using a $5^{\text {th }}$ order polynomial specification. Another way to address this issue is through the estimates of local linear regressions. In the local linear regression one estimates a linear regression using only data near the cutoff point, and allows the slope of the curve to differ to the left and right of the cutoff point. The local linear regression technique is equivalent to estimating two linear regressions: one using data just below the cutoff point and the other using data just above the cutoff point:

$$
\begin{aligned}
& \mathrm{Y}_{\mathrm{i}}=\alpha_{1}+\beta_{1}\left(\log \mathrm{W}_{\mathrm{i}, 2010}-\log _{\mathrm{M}} \mathrm{W}_{\mathrm{i}, 2010}\right)+\varepsilon_{\mathrm{i}} \\
& \text { Where } \operatorname{LogMW}_{\mathrm{i}, 2010}-\mathrm{h} \leq \log _{\mathrm{i}, 2010}<\operatorname{LogMW}_{\mathrm{i}, \mathrm{t2010}} \\
& \mathrm{Y}_{\mathrm{i}}=\alpha_{\mathrm{r}}+\beta_{\mathrm{r}}\left(\log \mathrm{W}_{\mathrm{i}, 2010}-\log \mathrm{MW}_{\mathrm{i}, 2010}\right)+\varepsilon_{\mathrm{i}} \\
& \text { Where } \operatorname{LogMW}_{\mathrm{i}, 2010} \leq \log _{\mathrm{i}, 2010}<\operatorname{LogMW}_{\mathrm{i}, 2010}+\mathrm{h}
\end{aligned}
$$

Or equivalently 


$$
\begin{gathered}
\mathrm{Y}_{\mathrm{i}}=\alpha_{1}+\tau \mathrm{D}_{\mathrm{i}}+\beta_{1}\left(\log _{\mathrm{i}, 2010}-\operatorname{LogMW}_{\mathrm{i}, 2010}\right)+\left(\beta_{\mathrm{r}}-\beta_{1}\right) \mathrm{D}_{\mathrm{i}}\left(\log _{\mathrm{i}, 2010}-\operatorname{LogMW}_{\mathrm{i}, 2010}\right)+\varepsilon_{\mathrm{i}} \\
\text { If } \operatorname{LogMW}_{\mathrm{i}, 2010}-\mathrm{h} \leq \log _{\mathrm{i}, 2010}<\operatorname{LogMW}_{\mathrm{i}, 2010}+\mathrm{h}
\end{gathered}
$$

Where $\mathrm{i}=$ worker, $\mathrm{Y}_{\mathrm{i}}=$ the outcome variable (i.e. $\log \mathrm{W}_{\mathrm{i}, 2011}-\log \mathrm{W}_{\mathrm{i}, 2010}$ ), $\beta_{\mathrm{r}}$ is the value of the regression to the right of the cutoff, $\beta_{1}$ the value of the regression to the left of the cutoff and $\varepsilon_{\mathrm{i}}=$ random error. $\mathrm{h}$ is the bandwidth; this is the local area around the cutoff point from which we draw the data to estimate the local linear regressions. We estimate equation 3 , where $\tau$ is the RD estimate of the treatment effect $\left(\alpha_{r}-\alpha_{l}\right)$.

As suggested by Lee and Lemieux (2010) and Imbens and Lemieux (2008), we estimate the local linear regressions using a rectangular kernel where all points within a bandwidth are weighted equally no matter the distance from the cutoff. In this case, the results are simply the average value of the outcome within a bandwidth. We also estimate the local linear regressions using a triangular kernel where weights attached to each observation within a bandwidth decrease linearly as the distance to the cutoff point increases. One advantage over the rectangular kernel is that the triangular kernel has been shown to perform better at the boundary by adjusting to account for fewer data points around the cutoff (Fan and Gijbels,1996 and Cheng et al. 1997).

One difficulty with the local linear regression approach is how to choose the appropriate bandwidth $\mathrm{h}$. The bandwidth must be small enough to reasonably expect the relationship between the assignment variable and outcome variable to be linear but wide enough so that there are sufficient observations within the bandwidth to confidently estimate the regression parameters. We report estimates for a variety of bandwidths to show that our estimates are not sensitive to the bandwidth choice. We choose our range of bandwidths in two ways. First, through an ad-hoc examination of a non-parametric estimate of the relationship between the assignment variable and outcome variable. Second, we also present non-parametric estimates of the regression discontinuity for a range of bandwidths chosen using the technique presented in Imbens and Kalyanaraman (2009), which minimizes the mean square error of the difference between the predicted and actual outcome variables. 


\section{Results: The Impact on Compliance and Wages}

We first examine if there is evidence that the Campaign for Minimum Wages increased compliance with legal minimum wage legislation in Costa Rica. That is, we examine the change in wages for worker i between 2010 and 2011. If the wages of workers who were earning below the minimum wage increased by more than the wages of those who were earning above the minimum wage, this would be evidence that the Campaign increased compliance with minimum wage legislation.

\section{(i) Descriptive statistics}

If the Campaign for Minimum Wages increased compliance with minimum wage legislation, we would expect to see the proportion of workers earning less than the minimum wage to fall from 2010 to 2011 and the proportion of workers earning equal to the minimum wage to increase. To explore whether we can identify an impact of the Campaign for Minimum Wages we examine the changes in the distribution of wages between 2010 and 2011, figure 4 presents kernel density estimates of the distribution of the log of wage minus the log minimum wage for each private sector employee. In figure 4 a zero indicates that the worker is earning the minimum wage applicable to that workers occupation, skill level and education; a negative number indicates that the worker is earning below the minimum wage; and a positive number indicates that the worker is earning above the minimum wage. In both 2010 and 2011, there is a spike in the distribution of wages at the minimum wage, but the spike is bigger in 2011. This illustrates that the proportion of workers earning at the minimum wage increased from 2010 to 2011. There are also fewer people earning below the minimum wage in 2011 compared to 2010, while the distribution of workers earning above the minimum wage is similar in 2010 and 2011. Specifically, the proportion of full-time private sector employees earning below $95 \%$ of the minimum wage falls from $33 \%$ in 2010 to $31 \%$ in 2011 , while the proportion of employees earning within $5 \%$ of the minimum wage increases from $11 \%$ to $13 \%$. The proportion of employees earning above the minimum wage did not change between 2010 and 2011, remaining at 56\%. This evidence is consistent with the hypothesis that many workers earning below the minimum wage before the Campaign had their wages increased to the minimum wage after the Campaign, but that the 
Campaign did not affect the distribution of wages for those workers whose wages were already above the minimum wage.

The regression discontinuity estimates presented in the next subsection compare the changes in wages from before and after the campaign for those who earned below the minimum wage in 2010 to those who earned above the minimum wage. Table 3 presents the changes in mean log monthly earnings between 2010 and 2011 for workers who were below and above the minimum wage in 2010 (using bandwidths of $1 \%, 5 \%$ and $10 \%)^{9}$. The final row of Table 3 can be interpreted as rough, non-parametric, estimates of the effect of the Campaign on wages. Table 3 shows that, after the implementation of the Campaign for Minimum Wages, the earnings of those who had earned below the minimum wage increased approximately $10 \%$ more than the earnings of those who had earned above the minimum wage. The evidence is consistent with the hypothesis that the Campaign caused the wages of those below the minimum wage to increase, implying increased compliance with minimum wages.

\section{(ii) Regression Discontinuity Estimates}

Figure 5 is a graphical representation of the regression discontinuity estimate of the impact of the Campaign for Minimum Wages (this is an estimate, using our data, similar to the stylized figure 2). Figure 5 is consistent with the hypothesis that the Campaign increased compliance with minimum wages for workers who had been earning just below the minimum wage. Figure 5 shows that when the Campaign was implemented, earnings increased more for those who had been earning below the minimum wage when compared to earnings changes for those who had been earning above the minimum wage. Over the entire sample, there is a trend where earnings increased more for those whose earnings are lowest (relative to the minimum wage). However, the earnings of those earning just below the minimum wage increased more than the overall trend would suggest, while the earnings of those just above the minimum wage increased by less. That is, there is a clear discontinuity at the cutoff point-workers earning just below the minimum wage before the Campaign saw their wages increase by more than those earning just above the minimum wage. Again, this is evidence that the Campaign increased compliance with minimum wages in Costa Rica. The evidence from figure 5 suggests that the Campaign had the

\footnotetext{
${ }^{9}$ Wage changes are reported for workers who are full-time private sector employees in both years.
} 
biggest impact on the wages of those who were earning within $15 \%$ of the minimum wage. There is a clear change in the pattern of the relationship between wages in 2010 and wage changes for workers earning from 0 to $15 \%$ below the minimum wage; for these workers wages increase by more than the overall pattern would suggest.

Table 4 presents RD estimates of the impact of the Campaign on wage changes, estimated for a variety of bandwidths and techniques for addressing non-linearities. Specifically, we present estimates using the entire data set and a flexible functional form; a $5^{\text {th }}$ order polynomial. We also present non-parametric local linear regression estimates of equation 3 using bandwidths suggested by figure 5 ( 0.10 and $0.15 ; 10-15 \%$ above and below the cutoff point). Finally, we present non-parametric RD estimates using the "optimal" bandwidth derived from the technique suggested by Imbens and Kalyanaraman (2009). ${ }^{10}$ The RD estimates reported in table 4 are consistent across all specifications, and suggest that the Campaign for Minimum Wages caused the earnings of those earning just below the minimum wage to increase by about 10 percent more than the increase in the wages of those earning just above the minimum wage. These estimates are positive in all specifications and statistically significant at the 5\% level in almost all specifications.

Table 5 adds covariates to the local linear regression (age, gender, firm size, education, whether the worker belongs to a union or solidarity organization, and a set of dummy variables indicating the industry sector). Including covariates may increase the precision of the regression discontinuity estimates (Lee and Lemieux, 2010). In our case, adding covariates to our RD regressions slightly lowers the regression discontinuity estimates of the impact of the Campaign. However, the RD estimates remain positive and the majority are statistically significant at the $10 \%$ level.

To test which groups were most affected by the Campaign for Minimum Wages, we estimate the impact separately for different sub-sets of the population. Table 6 presents RD estimates of the

\footnotetext{
${ }^{10}$ Inbens and Kalyanaraman (2009) start with a bandwidth that minimizes the mean squared error of the difference between the predicted outcome of the regression and the actual outcome. However, Imbens and Kalyanaraman (2009) note that because this is based on the entire sample, it may be an overestimate of the truly optimal bandwidth. They suggest using $1 / 2$ of this bandwidth might be more appropriate. In table 4 , we present estimates using half the "optimal" $(0.21)$.
} 
impact of the Campaign separately for: men vs. women; youth (15-24) vs. older workers; workers with two levels of education, and workers in different firm sizes. ${ }^{11}$ These results suggest that the Campaign for Minimum Wages had a larger positive wage impact on women compared to men, and youth compared to older workers. The estimated impact of the Campaign on the mean earnings of women was $16 \%$ to $27 \%$ (based on bandwidth specifications), while the estimated impact on the mean earnings of men was only 5\% to $9 \%$ (and statistically insignificant). The estimated impact of the campaign on the mean earnings of youth was $11 \%$ to $18 \%$, and is higher than the estimated impact on the wages of older workers in all specifications. The estimated impact of the Campaign on the earnings of workers with a primary or secondary education was positive and statistically significant, while the Campaign had a statistically insignificant impact on the earnings of those workers with a university education. These results may reflect the fact that a larger proportion of women, younger workers and less-educated workers earned below the minimum wage in 2010 and therefore more of them are likely to be affected by the campaign compared to men, older workers and workers with a university education. ${ }^{12}$

The results presented in table 6 also suggest that the Campaign was more likely to significantly affect workers in small- and medium-sized firms (6 to 100 workers) compared to workers in large firms (more than 100 workers) or micro-firms (less than 6 workers). The estimated impact on workers in small- and medium-sized firms is statistically significant, while the impact on workers in micro- or large firms is statistically insignificant. This may be because large firms were already paying workers more than minimum wage before the Campaign, while micro-firms largely remained non-compliant after the Campaign. ${ }^{13}$

\footnotetext{
${ }^{11}$ These estimates do not include control variables.

${ }^{12}$ In our interviews with labor inspectors, it was made clear to us that labor violations pertaining to female and youth workers were top priorities for labor inspectors (and the Ministry of Labor). When conducting full inspections, inspectors were instructed to pay particular attention to, but not limit themselves to, sexual harassment, pregnancy discrimination, maternity leave violations, and child and youth labor violations. It could be that the inspectors, even in inspections targeted towards minimum wage violations, paid particular attention to female and youth workers and/or firms with a high percentage of female and youth workers, contributing to a greater increase in compliance within these two groups.

${ }_{13}$ The Campaign had two broad components designed to increase compliance with minimum wage legislation: (a) an attempt to change the "social norm" through publicity and (b) an attempt to increase the cost of non-compliance through increased inspections. There is a debate in the literature about whether penalties or persuasion and publicity is the most effective way of efficiently enforcing labor regulations in developing countries (i.e. Amengual, 2010; Pires, 2008; Piore and Schrank, 2008). It would be of interest
} 
(iii) Testing for a placebo effect: does the RD technique find an impact on the wages of the selfemployed?

In practice, self-employed workers are not covered by minimum wage legislation. This is because self-employed workers cannot be forced to pay themselves the minimum wage. Therefore, we should not see the wages of self-employed workers who had been earning below the minimum wage before the campaign increase by more than the wages of the self-employed who had been earning above the minimum wage. If we find that this is happening among the self-employed as well as among private sector employees, then it is likely that the results presented in the last subsection are not due to the Campaign for Minimum Wages, but due to measurement error or some other phenomenon that affects both private sector employees and the self-employed. To test for this possible "placebo" effect, we re-run our regression discontinuity analysis of the impact of the Campaign limiting our analysis to the self-employed rather than private sector employees.

Figure 6 presents kernel density estimates of the log of monthly earnings minus the log of the minimum wage for full-time self-employed workers in 2010 and 2011. Overall, the distributions for 2010 and 2011 look very similar. As in the distribution of paid employees, there is a large proportion of self-employed workers who report earnings below the legal minimum wage. Unlike in figure 4, using data for private sector employees, we do not see a larger spike in the distribution of self-employed earnings at the minimum wage in 2011 compared to 2010. If

to know which of these two components was most effective. As we showed in table A1, inspections affected a larger number and percentage of workers in commerce and manufacturing as opposed to other industries. If increased inspections are driving our results, we would expect to see a larger impact of the Campaign in commerce and manufacturing than in other industries. Table A3 in the appendix presents the estimated impact of the Campaign by industry. The results presented in table A3 do not provide consistent evidence that the impact of the campaign was larger in commerce and manufacturing than in other industries; estimated wage effects of the campaign are negative in commerce and positive in manufacturing and in each case the effects are also statistically insignificant. In another attempt to isolate the impact of publicity from inspections, we re-estimated our RD equations using data for domestic service workers only. Households, where domestic service workers are employed, were not subject to any increase in inspections. Therefore, if the Campaign had a positive impact on wages among domestic workers, this would be due to the publicity aspect of the campaign. However, we do not find an impact of the Campaign on domestic workers; the regression discontinuity estimate of the Campaign on domestic workers is negative and statistically insignificant (see the last rows of table A3). On balance, therefore, we cannot provide convincing evidence that either the publicity campaign or the inspections were the force driving the impact of the Campaign. 
anything, the spike at the minimum wage is larger in 2010 than in 2011. This evidence is consistent with the hypothesis that the Campaign had no impact on the distribution of earnings among self-employed workers.

Figure 7, the RD graphical representation for self-employed workers, shows that when the Campaign for Minimum Wages was implemented, earnings did not increase any faster for those who had been earning just below the minimum wage when compared to those who had been earning just above the minimum wage. There is a small discontinuity at the cutoff point, but it is statistically insignificant. Again, this suggests that the Campaign had no impact on the earnings of self-employed workers.

Table 7 presents the results of the RD regressions for self-employed workers. Table 7 suggests that the Campaign for Minimum Wages did not have a statistically significant impact on the wages of self-employed workers who had been earning below the minimum wage prior to the Campaign. ${ }^{14}$ This provides additional evidence to strengthen our conclusion that the Campaign had a positive causal impact on the wages of private sector employees who had been earning below the minimum wage before the Campaign.

\section{Results: The Impact on Employment}

In the last section, we concluded that the Campaign for Minimum Wages increased compliance with minimum wage legislation. That is, the Campaign caused employers who had been paying less than the minimum wage to some workers to increase the wages of these workers to the legal minimum. If the marginal productivity of minimum wage workers is less than the legal minimum wage, then the Campaign may have also caused some employers to fire the now-more-costly workers to whom they had been paying less than the minimum wage. To test for this possibility we conduct a regression discontinuity analysis similar to that in the last section, but replace the outcome variable with a measure of whether or not workers kept their jobs between 2010 and 2011.

\footnotetext{
${ }^{14}$ These results also hold when we add covariates to the RD regressions for the self-employed.
} 
Figure 8 presents a graph of the relationship between whether or not the worker was earning below the minimum wage in 2010 and the probability that a full-time private sector employee in 2010 is still a full-time employee in 2011. Over the entire sample, full-time private sector employees with earnings below the minimum wage in 2010 were less likely to remain full-time employees in 2011. However, figure 7 presents no clear evidence that this was true for those earning just below vs. just above the minimum wage in 2010. That is, there is no clear discontinuity. This suggests that the Campaign had no impact on the probability that a worker remained employed. ${ }^{15}$

Table 8 presents regression discontinuity estimates of the impact of the Campaign for Minimum Wages on the probability that a private sector worker remained employed from 2010 to 2011. The outcome variable in these regressions is a dummy variable that is one if worker i remains a full-time employee between 2010 and 2011, and zero if not. The first panel of table 8 presents the basic RD estimates; the second panel presents results where covariates are added to the regressions. ${ }^{16}$ The results of all RD estimates are consistent across all specifications: workers earning less than the minimum wage in 2010 were not less likely to remain employed in 2011. The RD estimates are positive (although statistically insignificant), which would suggest, if anything, that workers who had been earning less than the minimum were more likely to remain employed than workers who had been earning more than the minimum wage. That is, we find no support for the hypothesis that the Campaign for Minimum Wages resulted in employers firing the now-more-costly full-time workers to whom they had been paying less than the minimum wage. $^{17}$

\footnotetext{
${ }^{15}$ Contrary to results presented here, Gindling and Terrell (2007) showed that in Costa Rica a higher level of the minimum wage has a significant negative impact on employment. These results are consistent with other studies that present evidence of a negative employment impact of higher minimum wage levels in Latin America (i.e. Castillo-Freeman and Freeman, 1992). Our results are also consistent with those of Harrison and Scorse (2010) who present evidence that in Indonesia higher levels of the minimum wage results in reduced employment but that increased compliance does not.

${ }^{16}$ The full regression results of the employment regressions adding covariates are presented in table A4 of the appendix. We use a linear probability model (LPM) to estimate the employment equations. As a robustness check, we also estimate all regressions using a probit model. The estimated marginal effects from the LPM and Probit models are similar.

${ }^{17}$ In table A5 of the appendix, we also test the effect of the campaign on the probability of remaining employed for several subgroups. The results of our analysis are consistent for all subgroups and suggest no support for the hypothesis that the Campaign might have resulted in increased firing.
} 
Another possible reaction of employers when faced with a higher wage bill for full-time employees could be to reduce the number of part-time employees. We explore this possibility by re-estimating the $\mathrm{RD}$ employment regressions using data on workers who were part-time private sector employees in 2010 and where the dependent variable is equal to one if they remained employed in 2011 and zero if they are no longer employed in 2011. The results of these regressions, reported in table 9, suggest a negative but statistically insignificant effect of the Campaign on part-time employment. The statistical insignificance of this result may be related to a small sample size; compared to full-time workers there are relatively few part-time workers in the data. Table 9 thus provides some weak evidence that employers may have reduced part-time employment in response to the Campaign. ${ }^{18}$

\section{Results: The Impact on Non-Wage Benefits}

When faced with higher wages for workers previously earning less than the minimum wage, employers might react by reducing non-wage benefits for these workers. The impact may be different for voluntary non-wage benefits and non-wage benefits mandated by the labor code. We expect that the impact of the campaign on voluntary non-wage benefits would be negative. The campaign might also have a negative impact on legally mandated non-wage benefits because of a reduction in inspections of other labor code violations to accommodate the increased targeted inspections towards minimum wage violations. On the other hand, the Campaign could

\footnotetext{
${ }^{18}$ While we found no evidence that employers fired workers because they were forced to pay subminimum wage workers more, it is still possible that the employment opportunities for this group declined because of the Campaign. That is, employers may have reduced new hires of workers with subminimum wage productivity. To provide some evidence on this possibility, we test whether the Campaign led to reduced hiring of self-employed workers. Table A6 in the appendix presents regression discontinuity estimates of the impact of the Campaign for Minimum Wages on the probability that a fulltime self-employed workers transition into full-time private sector employment. The results are consistent across specifications and suggest that the campaign did not reduce the probability of transitioning into the covered sector for those who were self-employed in 2010. If anything, the results suggest that there was a small increase in the probability that a self-employed worker ended up as a full-time employee. Given the complex nature of the multiple minimum wage system in Costa Rica, it is also possible that employers could respond to the potential increases in the cost of employment brought about by increased compliance by reducing the hiring of workers into high minimum wage jobs and/or increasing hiring of workers into low minimum wage jobs (or even by simply "re-classifying" jobs from high minimum wage categories to lower minimum wage categories). To test for this possibility, we examined the impact of the campaign on the probability of transitioning from a low minimum wage jobs (unskilled or semi-skilled workers, representing over $55 \%$ of all private sector employees) to a higher minimum wage/higher skilled job. The results provide no evidence that the Campaign reduced the number of workers transitioning from low minimum wage to high minimum wage jobs.
} 
have had a positive impact on legally mandated wage benefits. For example, one goal of the Campaign was to "create a level of consciousness among employers and workers regarding the importance of complying with the minimum wage." A spillover benefit of the Campaign could have also been a broader change in the "social norm" leading to an increase in the level of consciousness regarding the importance of complying with all labor regulations. In addition, given the nature of the inspections, labor inspectors, by law, cannot reveal the reasons for their visits. In order to protect workers who might have filed a complaint from firing, demotion or discrimination, inspectors must maintain the anonymity of workers as well as the nature of the complaints. This too might lead to a general increase in compliance with all labor regulations. This section investigates the effect of the Campaign on the provision of legally mandated nonwage benefits and explores how employers responded to increased compliance with minimum wage legislation and a decrease in inspections of other labor violations.

Table 10 reports the RD estimates of the impact of the Campaign on the probability that a fulltime private sector employee receives several types of legally mandated non-wage benefits. ${ }^{19}$ The dependent variable is equal to one if the employee receives the non-wage benefit in 2011 . The RD results indicate that the campaign had a statistically significant and positive impact on the probability of receiving Social Security. Workers earning below the minimum wage in 2010 were on average 10 to 14 percent more likely to gain or keep their Social Security benefits compared to workers earning just above the minimum wage in 2010. The results are consistent and significant across all bandwidths and most specifications. ${ }^{20}$ The RD estimates also indicate positive and statistically significant impacts of the Campaign on the probability of receiving paid

\footnotetext{
${ }^{19}$ In Figure A2 of the appendix, we illustrate graphically the regression discontinuity of four legally mandated non-wage benefits. The top left panel in Figure A2 plots the impact of the Campaign on the probability of receiving Social Security (which includes both pensions and health insurance), while the top right panel plots the probability of receiving paid sick leave. The bottom left and right panels plot the probability of receiving paid vacation and paid overtime respectively. The data in Figure A2 show striking discontinuity in mandated non-wage benefit coverage for workers at the minimum wage threshold that suggests that the Campaign for Minimum Wages increased compliance with legally mandated non-wage benefits.

${ }^{20}$ We use a linear probability model (LPM) to estimate the equations reported in table 10 , but as a robustness check, we also estimate all regressions using a probit model. The estimated marginal effects from the LPM and Probit models are similar.
} 
vacation and paid overtime. $^{21}$ The results show a positive, but statistically insignificant, impact on the probability of receiving sick leave.

The final two rows in table 10 also show a positive and statistically significant impact of the Campaign on the probability that a worker who had been earning less than the minimum wage receives training. ${ }^{22}$ This is somewhat surprising given that one might expect employers to reduce this non-wage benefit as a way of reducing the labor costs. The increased training obtained by workers who had been earning less than the minimum wage could be driven by a desire on the part of employers to increase the productivity of these now more expensive workers. This result is consistent with Almeida and Aterido (2011), who find evidence using a large firm level data set across 63 countries that more stringently enforced labor regulations increase the probability of on-the-job training. Almeida and Aterido (2011) argue that this may be because stricter labor regulations create longer term firm-employer relationships which can, in turn, create a greater incentive for firms to invest in training. While we clearly do not find evidence that the Campaign led to reduced training of employees in private sector firms, we have to be careful interpreting this evidence. We cannot interpret this as direct evidence that employers provided more training because of the Campaign. This is because the variable we use identifies only whether or not the worker received training and not who paid for that training. It may be that this training was acquired and paid for by the workers independently.

\footnotetext{
${ }^{21}$ The results are particularly large and significant in the case of paid overtime; workers earning below the minimum wage were 10 to 24 percent (based on bandwidth specifications) more likely to be paid for extra hours worked compared to those earning just above the minimum wage. This large increase raises the question of whether the results could be attributed to the Campaign or some specification error. One possibility could be that workers earning below the minimum wage in 2010 were considerably undercompensated for extra hours worked. Another possibility for why we observe a higher effect in the case of paid overtime is that workers who earn below the minimum wage might be more inclined to work extra hours in order to supplement their low income. To test whether the large impact on paid overtime is due to extra hours worked or actual campaign effect we test the impact of the Minimum Wage Campaign on the change in hours worked for those working at least full-time in both periods. The results show negative and insignificant effects of increased enforcement on hours worked, leading to a conclusion that increased minimum wage enforcement has led to an increase in the probability of receiving overtime compensation for workers who had not been receiving overtime compensation before the Campaign.

${ }^{22}$ The variable that we use to measure the impact of increased compliance on the probability that employers will reduce training indicates whether an individual obtained training or education that was not obtained through the formal educational system.
} 


\section{Conclusions}

In August 2010 the Costa Rican government implemented a comprehensive program to increase compliance with legal minimum wages, the Campaign for Minimum Wages. To evaluate the impact of the Campaign, we use a regression discontinuity approach, which compares what happened to workers who before the campaign had been earning below the minimum wage to those who before the Campaign had been earning above the minimum wage. We analyze a panel data set with information on workers from before the Campaign began (July, 2010) and after the Campaign had been in operation for some time (July, 2011). We find evidence that the Campaign led to an increase in compliance with minimum wage laws in Costa Rica; the mean earnings of those earning less than the minimum wage in 2010 increased by approximately $10 \%$ more than the earnings of those who had been earning more than the minimum wage. We find evidence that the Campaign led to the largest increases in the wages of women, younger workers and less-educated workers.

We find no evidence that the Campaign had a negative impact on the employment of full-time workers whose wages were increased. We find some weak evidence that the Campaign had a negative impact on the employment of part-time private sector employees.

The results presented in this paper are based on data from the first year of the Campaign, and as such represent short-run results. It is possible that the observed increased compliance and wage gains brought about by the Campaign could be temporary: if the Campaign does not continue then labor markets may return to the status quo prior to the campaign. On the other hand, it may take firms time to adjust to higher costs, and by looking only at the first year of the Campaign we may be missing long-term adjustments to investment, technology, etc. that could reduce employment. However, previous research (Gindling and Terrell, 2007) has shown strong and consistent evidence that wages and employment adjust rapidly in Costa Rica to changes in the level of the minimum wage. Given this, we expect the Costa Rican labor market also to react rapidly to the Campaign for Minimum Wages.

Although increased inspections were mainly targeting minimum wage violations, we observe an increase in compliance with a broader set of labor standards and a positive spillover effect 
relative to other violations of labor laws. Specifically, the analysis provides evidence that the Campaign had a positive impact on the probability that workers receive legally mandated nonwage benefits such as Social Security (which includes pension and health insurance), overtime pay, sick-leave and paid vacations. One explanation of our findings is that the media campaign raised general awareness of the importance of workers' labor rights amongst both employees and employers. It is possible that the increased awareness led to a comprehensive change in social norms related to labor violations on the part of employees who are now more knowledgeable about their rights and on the part of employers who prefer to avoid social stigma or embarrassment by complying with labor laws. ${ }^{23}$ Another explanation of the Campaign's positive impact on non-wage benefits may be the fact that labor inspectors are forbidden to disclose to an employer whether the visit is a result of a complaint or a general random inspection. This in turn might have led to a general increase in compliance with all labor regulations. One conclusion to be drawn from this analysis is that strong government enforcement and promotion of one aspect of labor regulations can lead to increased compliance of other labor regulations.

\footnotetext{
${ }^{23}$ Increased inspections and increased publicity may be complementary. For example, Piore and Schrank (2008) write that "By consciously advertising their existence, making their presence felt in provincial towns as well as capital cities, and actively courting such participation, labour ministries can go a long way toward making labour inspectors publicly accountable" (p. 18). Pires (2008) presents evidence that in Brazil "Labour inspectors have been able to promote sustainable compliance...by combining punitive and pedagogical inspection practices" (p. 199) something similarly carried out by the Costa Rican labor inspectors.
} 


\section{References}

Aghion, Philippe, Yann Algan and Pierre Cahuc. 2011. "Civil Society And The State: The Interplay Between Cooperation And Minimum Wage Regulation." Journal of the European Economic Association, vol. 9 No. 1 (February), pp. 3-42.

Almeida, Rita and Reyes Aterido. 2011. "On-the-job Training and Rigidity of Employment Protection in the Developing World: Evidence from Differential Enforcement." Labour Economics, Vol. 18, Supplement 1 (December), pp. S71-S82.

Almeida, Rita and Z. Bilgen Susanli. 2012. "Firing Regulations and Firm Size in the Developing World: Evidence from Differential Enforcement." Review of Development Economics, Vol. 16, No. 4 (November), pp. 540-558.

Almeida, Rita and Pedro Carneiro. 2011. "Enforcement of Labor Regulation and Informality." IZA Discussion Paper No. 5902.

Almeida, Rita and Pedro Carneiro. 2009. "Enforcement of Labor Regulations and Firm Size." Journal of Comparative Economics, Vol. 37, No. 1 (March), pp. 28-46.

Amengual, Matthew. 2010. “Complementary Labor Regulation: The Uncoordinated Combination of State and Private Regulators in the Dominican Republic." World Development, Vol. 38, No. 3 (March), pp. 405-414.

Arias, Randall (Programa Cumple y Gana). 2011. "Consideraciones Sobre el Impacto de la Política Pública para el Complimiento del Salario Mínimo en Costa Rica." presented at the Seminario Internacional Reflexiones en Torno al Salario Mínimo, October 11, San José Costa Rica.

Basu, Arnab, Nancy Chau and Ravi Kanbur. 2010. "Turning a Blind Eye: Costly Enforcement, Credible Commitment and Minimum Wage Laws.” The Economic Journal, Vol. 120, No. 543 (March), pp. 244-269.

Castillo-Freeman, A. and R. Freeman. 1992. "When the Minimum Wage Really Bites: The Effect of the U.S.-level Minimum Wage on Puerto Rico." In Immigration and the Workforce: Economic Consequences in the U.S. and Source Countries, G. Borjas and R. Freeman (eds.) NBER Conference Volume, Chicago: University of Chicago Press.

Cheng, Ming -Yen, Fan Jianqing, and J. S. Marron. 1997. "On automatic boundary corrections". Annals of Statistics, Vol. 25, No. 4, pp. 1691-1708.

Cunningham, Wendy. 2007. Minimum Wages and Social Policy: Lessons from Developing Countries. Washington, D.C.: The World Bank.

Fan, Jianqing and Irene Gijbels. 1996. Local Polynomial Modeling and its Applications. London: Chapman and Hall. 
Estado de la Nación. 2009. Informe Anual del Estado de la Nación. San Jose, Costa Rica, October.

Gindling, T.H. and Katherine Terrell. 2007. "The Effects of Multiple Minimum Wages throughout the Labor Market: the Case of Costa Rica." Labour Economics, Vol. 14, No. 3 (June), pp. 485-511.

Gindling, T.H. and Katherine Terrell. 2005. "Legal Minimum Wages and the Wages of Formal and Informal Sector Workers in Costa Rica." World Development, Vol. 33, No. 11 (November), pp. 1905-1921.

Gindling, T.H. and Katherine Terrell. 1995. "The Nature of Minimum Wages and Their Effectiveness as a Wage Floor in Costa Rica." World Development, Vol. 23, No. 8 (August), pp. 1439-1458.

Gindling, T. H. and Juan Diego Trejos. 2010. Reforzar el complimiento de los salaries mínimos en Costa Rica, FUSADES, San Salvador.

Harrison, A. and J. Scorse. 2004. "The Impact of Globalization on Compliance With Labor Standards: a Plant-level Study." In S. Collins and D. Rodrik, eds., Brookings Trade Forum 2003. Washington, D.C.: Brookings Institution Press.

Harrison, A. and J. Scorse. 2010. "Multinationals and Anti-Sweatshop Activism," American Economic Review 100(1), pp. 247-2 73.

Imbens, Guido and Karthik Kalyanaraman. 2009. "Optimal Bandwidth Choice for the Regression Discontinuity Estimator.” NBER Working Paper No. 14726.

Imbens, Guido W. and Thomas Lemieux. 2008. "Regression discontinuity designs: A guide to practice," Journal of Econometrics, vol. 142, No. 2 (February), pp. 615-635.

Lee, David S. 2008. "Randomized Experiments from Non-random Selection in U.S. House Elections.” Journal of Econometrics, Vol. 142, No. 2 (February), pp. 675-697.

Lemos, Sara. 2004. "The Effects of the Minimum Wage in the Formal and Informal Sectors in Brazil.” IZA Discussion Paper No. 1089.

Lee, David S. and Thomas Lemieux. 2010. "Regression Discontinuity Designs in Economics." Journal of Economic Literature, Vol. 48, No. 2 (June), pp. 281-355.

McCrary, Justin. 2008. "Manipulation of the Running Variable in the Regression Dis- continuity Design: A Density Test," Journal of Econometrics, Vol. 142, No. 2 (February), pp. 698714. 
Ministerio de Trabajo, Dirección de Planificación del Trabajo, Observatorio del Mercado Laboral, "Situación Actual del los Salarios Mínimos en Costa Rica," October, 2011.

Pires, Roberto. 2008. "Promoting Sustainable Compliance: Styles of Labour Inspection and Compliance Outcomes in Brazil." International Labour Review, Vol. 147, No. 2-3, pp. 199-229.

Piore, Michael J., and Andrew Schrank. 2008. "Toward Managed Flexibility: The Revival of Labour Inspection in the Latin World, International Labour Review, Vol. 147, No. 1, pp. $1-23$.

Piszk, Sandra. 2011. "Resultados del primer año de la Campaña Nacional de Salarios Mínimos." Seminario Internacional Reflexiones en Torno al Salario Mínimo, October 11, San José Costa Rica.

Ronconi, Lucas. 2008. "Enforcement and Compliance with Labor Regulations." Industrial and Labor Relations Review, Vol. 63, No. 4 (October), pp. 719-736.

Strobl, E. and F. Walsh. 2001. "Minimum Wage and Compliance: the Case of Trinidad and Tobago." Economic Development and Cultural Change, Vol. 51, No. 2 (January), pp. $427-450$.

Van der Klaauw, Wilbert. 2008. "Regression-Discontinuity Analysis: A Survey of Recent Developments in Economics." Labour, Vol. 22, No. 2, pp. 219-245. 


\section{Appendix 1: Testing key assumptions of the regression discontinuity approach}

A key assumption of the regression discontinuity approach is that workers just below the cutoff are systematically similar to workers just above the cutoff, except for the fact that they have been treated (Imbens \& Lemieux, 2008; McCrary, 2008; Van der Klaauw, 2008). In our context, this assumption would be violated if there were non-random differences in the observable or unobservable characteristics between workers earning just below vs. just above the minimum wage in 2010. This could occur if employers intentionally choose which sub-minimum wage worker gets a wage below the legal minimum wage and which gets a wage above the legal minimum wage, or if workers have control over who earns above or below the minimum wage. According to the regression discontinuity literature, knowledge and manipulation of treatment assignment rules may generate unexpected behavioral responses from employees or employers (Imbens \& Lemieux, 2008; McCrary, 2008; Van der klaauw, 2008). Either can invalidate the comparability of workers near the threshold because of sorting around the cut off, where those below the minimum wage might differ on average from those just above.

There might be reasons to believe that workers have been sorted on unobserved characteristics such as innate ability, power to negotiate, knowledge of minimum wage laws and so on. If this holds, the key identifying assumption behind the RD design will be violated and the results will be subject to selection bias. The key question is whether this is a precise or imprecise manipulation of the assignment variable. Under imperfect "imprecise" manipulation, the continuity assumption holds (Lee, 2008) due to some random element as to who gets bumped above the minimum wage and who does not.

These assumptions imply that the distribution of the assignment variable will be continuous at the cut-off point. McCrary $(2008)^{24}$ developed a formal test of manipulation based on an intuition that density to the right of the cut-off of the assignment variable will be considerably

\footnotetext{
${ }^{24}$ In practice, McCrary's test is executed in two steps as follows: the first step involves plotting a very under smoothed histogram. The bins for the histogram are defined so that no bin includes points both to the left and right of the discontinuity point. The second step is a local linear regression of the histogram separately on either side of the cutoff. The midpoints of the histogram bins are treated as a regressor in the regression, and the normalized counts of the number of observations into each bin are treated as an outcome variable. Finally, the discontinuity at the cutoff is then estimated as the log difference in height on the intercept.
} 
different than to the left of the cut-off under complete manipulation of the assignment variable. Lee and Lemieux (2010) show examples of densities of forcing variable under three conditions; complete, imprecise and precise manipulation. Under imprecise manipulation, believed to be the case in our RD design, if workers or employers cannot precisely control the assignment variable, then the expected density of the assignment variable should be continuous around the discontinuity point as shown in figure A1. That is, figure A1 suggests that our data pass the McCrary test.

McCrary (2008) points out that such a density test is only informative if manipulation is monotonic, where the treatment induces agents (workers and employers) to change the assignment variable in one direction only and that the absence of a discontinuity in the density of the assignment variable is neither a necessary nor a sufficient condition for valid inference (McCrary, 2008 p.5). Another validity test is to examine the comparability of worker on either side of the threshold. Ideally, workers earning just below the minimum wage should on average have similar observed and unobserved characteristics to those earning just above the minimum wage.

We can plot the average of the covariates against the assignment variables on either side of the threshold and see if a discontinuity exits. An alternative method is to use the covariates as the dependent variable and run a regression discontinuity using the assignment variable as the independent variable (Imbens \& Lemieux, 2008; van der Klaauw, 2008; Lee \& Lemieux, 2010). We conduct such an analysis using our data and the covariates considered in the paper. The results are reported in table A7. We find sharp discontinuities in the distribution of several worker characteristics around the cutoff threshold. This includes discontinuities in the variables gender, educational level and industry type. For example, male workers are significantly more likely to earn above the minimum wage (that is, there is a higher concentration of male workers above the cut-off compared to women), as are workers with more education. In addition, there is evidence that it is significantly more probable that workers just below the minimum wage work in construction, manufacturing, agriculture and manufacturing (compared to those working in commerce, finance, and services). ${ }^{25}$ Thus, the treatment (the campaign) is confounded with

\footnotetext{
${ }^{25}$ Assignment to above or below the minimum wage does not depend on whether the worker is in a small
} 
relative observed worker characteristics that might be associated with the earlier finding of sorting close to the cut-off and might undermine the reliability of the RD design.

In principle, the regression discontinuity design conditional on worker covariates (i.e.

educational level, gender and industry) should reduce the problem of sorting. In the body of this paper we present $\mathrm{RD}$ estimates that include these variables as covariates, as well as RD estimates of the impact of the campaign for workers with each of these characteristics (i.e. by gender and education level). The results of all our estimates are consistent and show that the Campaign did have a positive impact on wages and compliance. However, if additional unobserved factors such as skills jointly determine the likelihood of earnings at or above the minimum wage, then sorting might persist and can invalidate the underlying RD identification assumptions, and straightforward RD estimates would be subject to selection bias.

firm or is a member of a union or solidarity organization. 
Figure 1: Components of the publicity campaign illustrated on a Ministry of Labor web site facebook \& $L^{\frac{1}{4}} s^{3} \sqrt{\text { Search }} Q$

Piezas de la Campaña Nacional de Salario Mínimo Like By Ministerio de Trabajo y Seguridad Social - View Photos
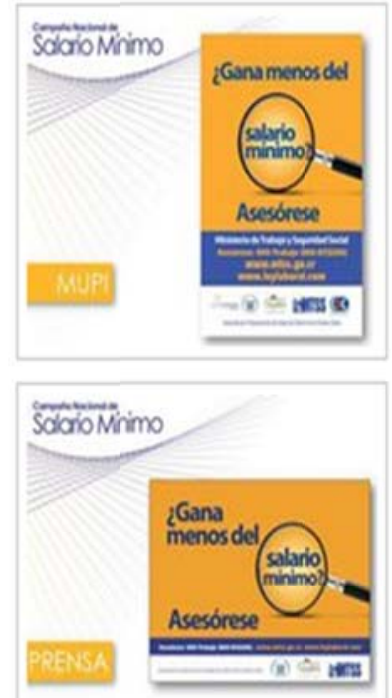
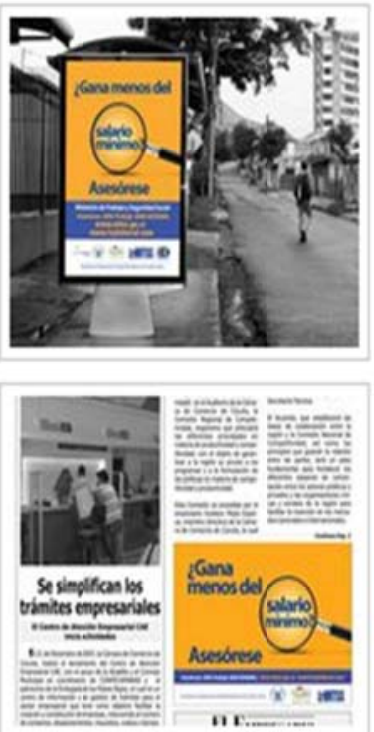
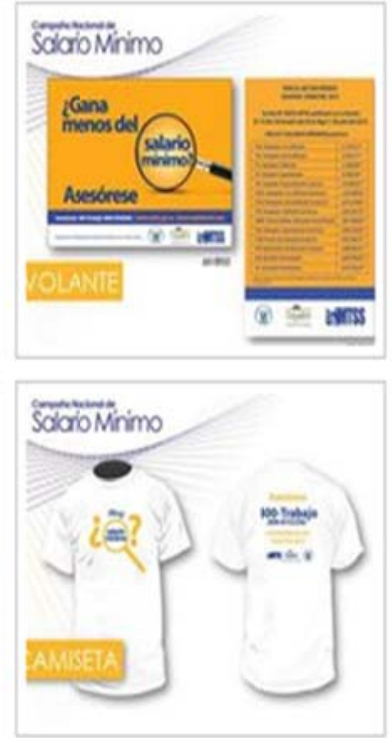
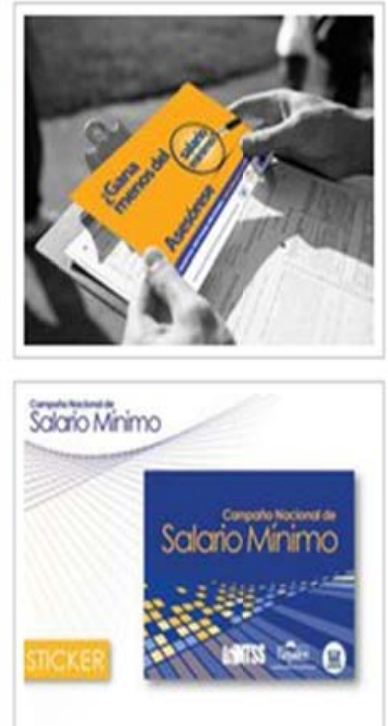
Figure 2: Evolution of minimum wages, real GDP and unemployment, 1995-2011

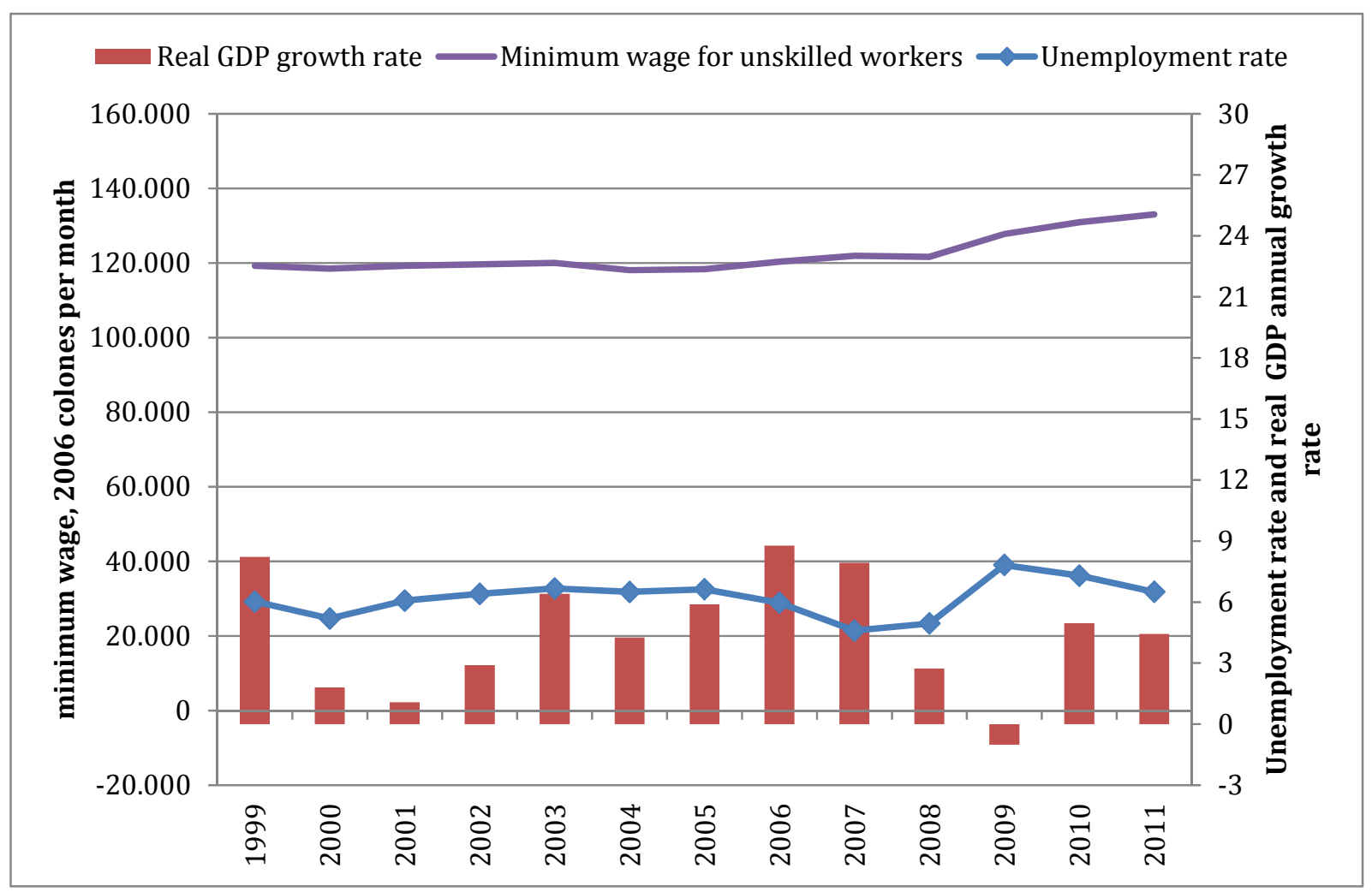

Source: Central Bank of Costa Rica, National Institute of Statistics and Census and minimum wage decrees. 
Figure 3: Potential impact of the Campaign on wages and compliance.

Panel A: Assuming a linear relationship between the assignment variable and outcome variable:

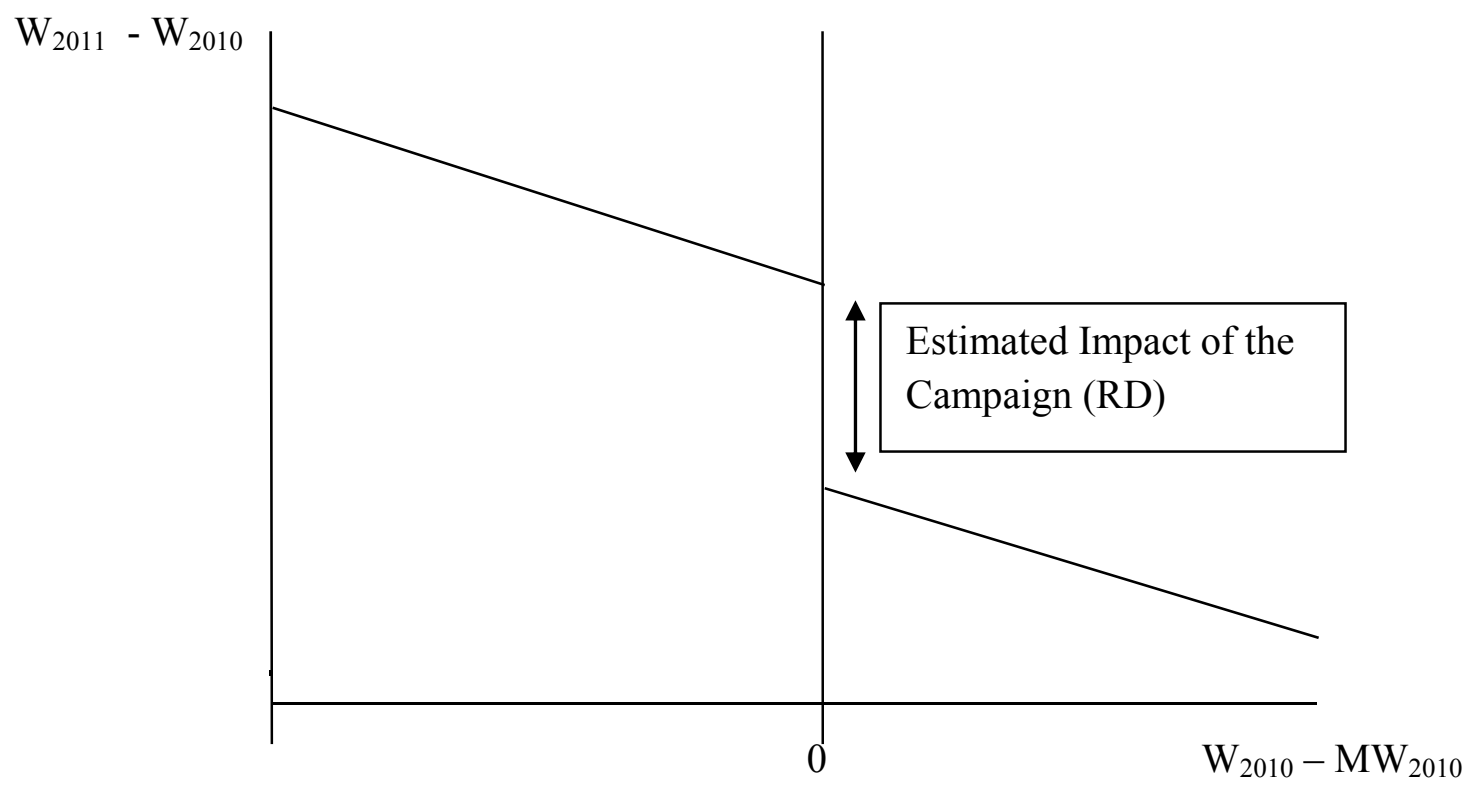

Panel B: Assuming a non-linear relationship between the assignment variable and outcome variable:

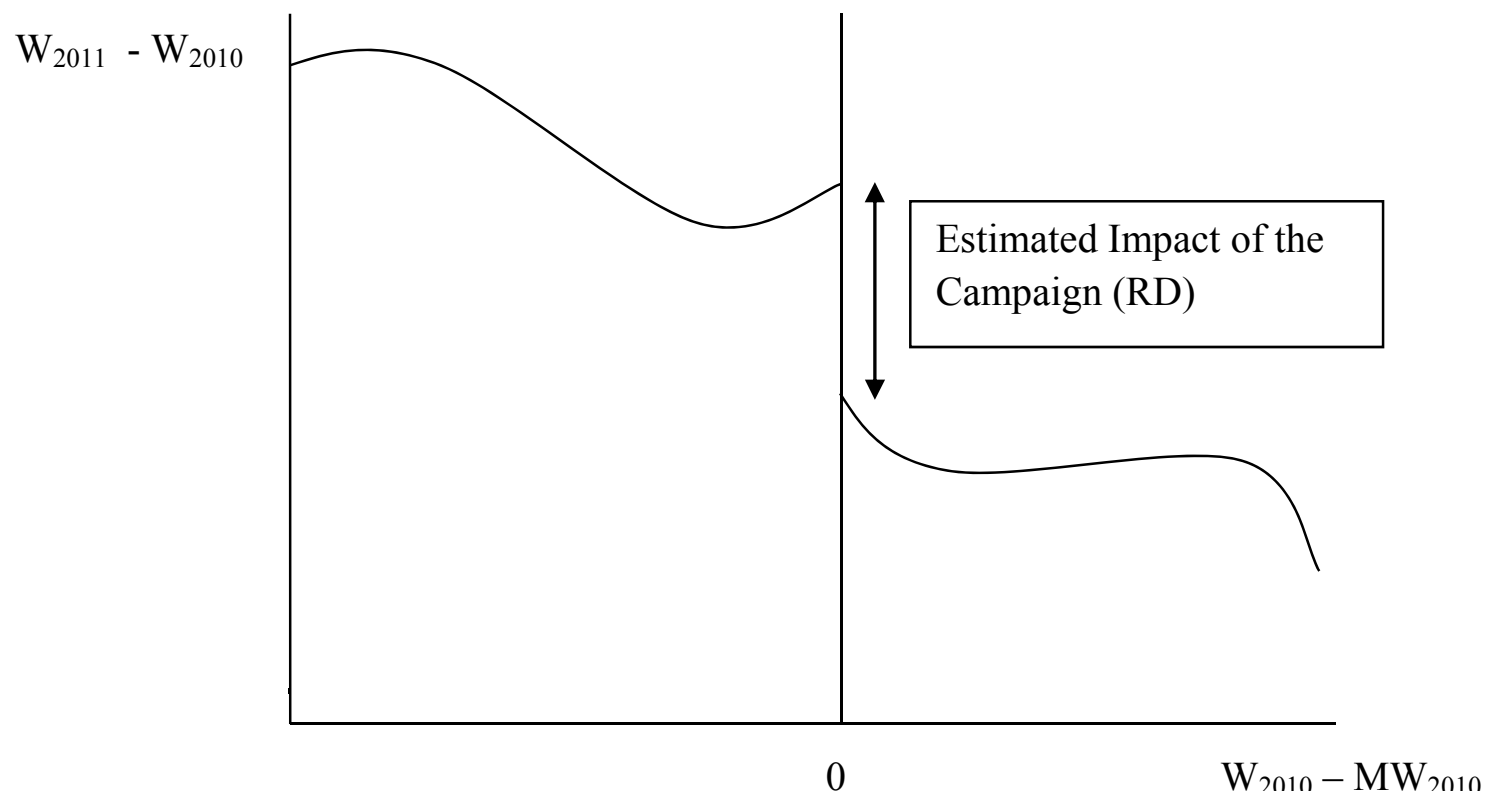


Figure 4: Kernel density estimates of the distribution of the log of monthly earnings relative to the legal minimum wage,

for full-time private sector employees in 2010 and 2011

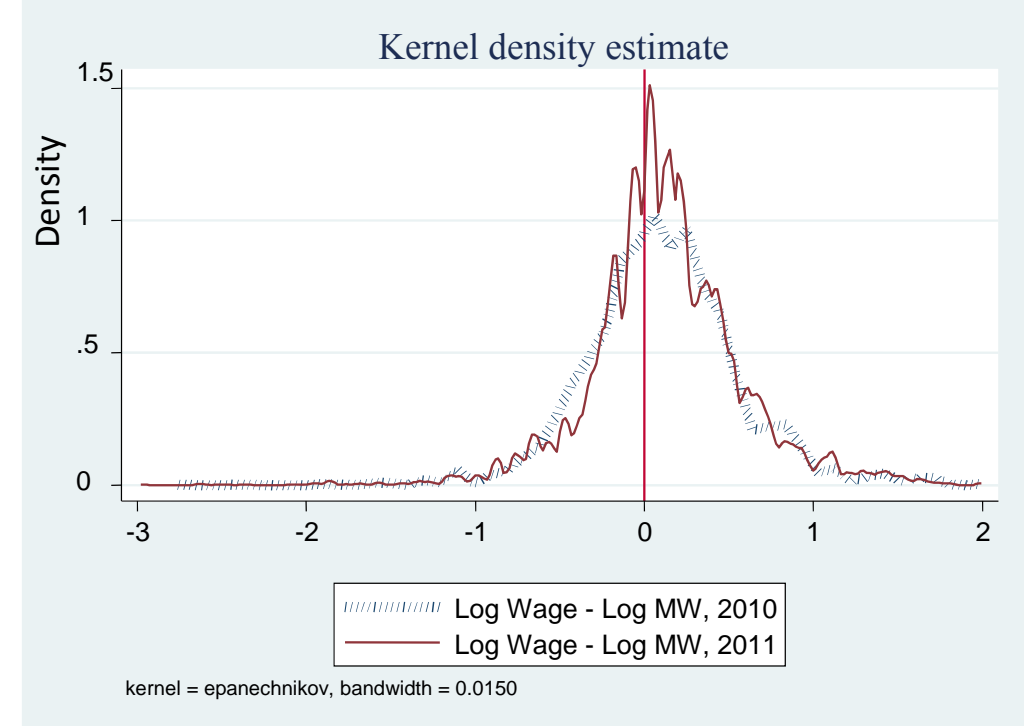

Figure 5: Graphical representation of regression discontinuity estimate of the impact on wages of full-time private sector employees

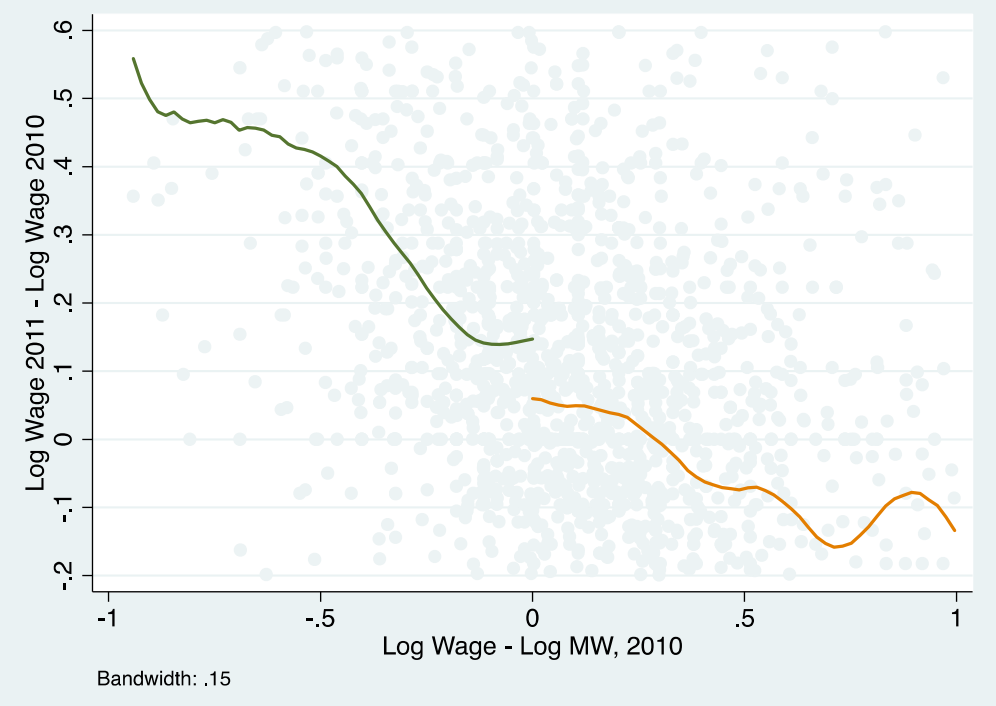

Notes: Estimated discontinuity $=.095$, standard error $=.046$. 
Figure 6: Placebo/falsification Test: Kernel density estimates of the distribution of the log of monthly earnings relative to the legal minimum wage for full-time self employed workers in 2010 and 2011

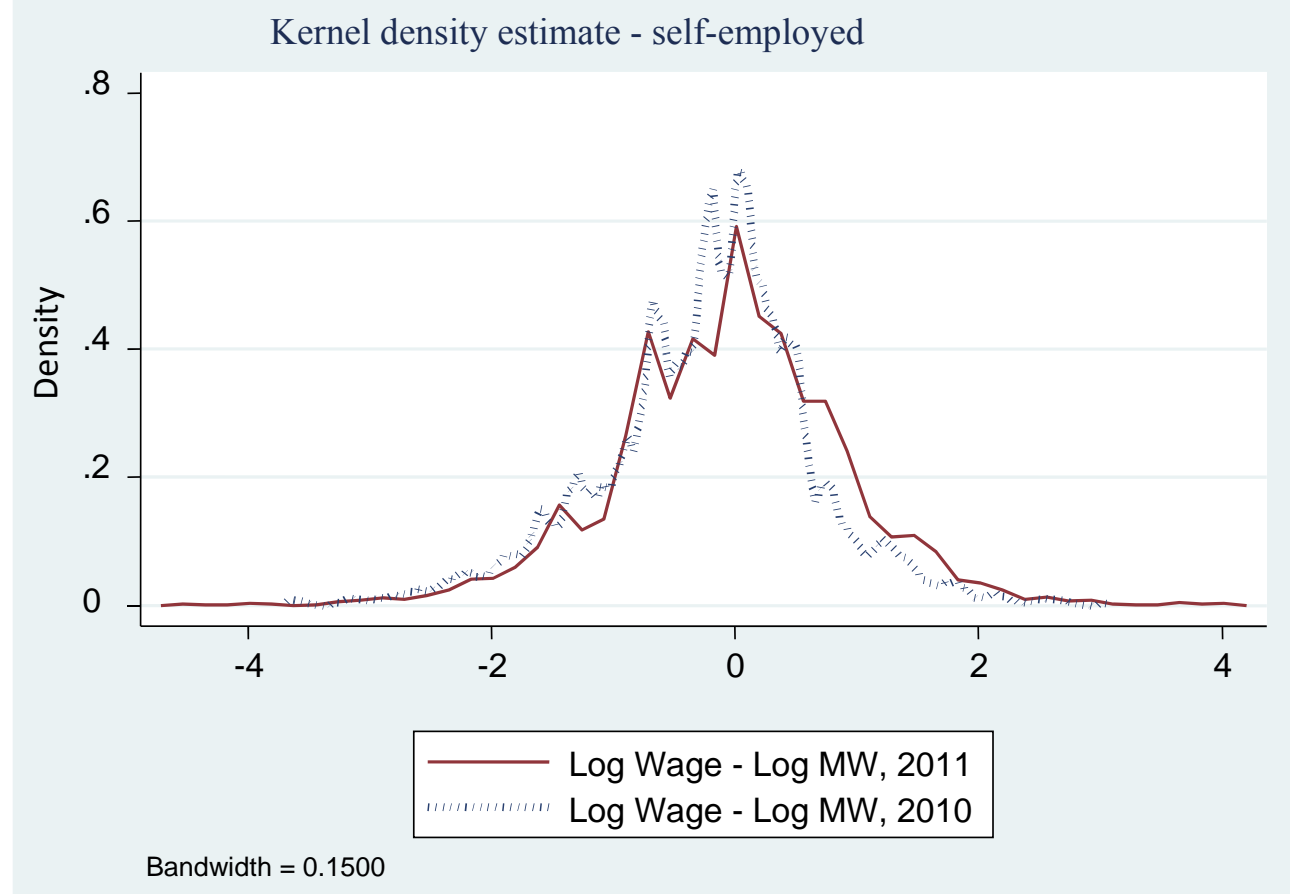

Figure 7: Graphical representation of regression discontinuity estimate of impact on wages, self employed workers in 2010 and 2011

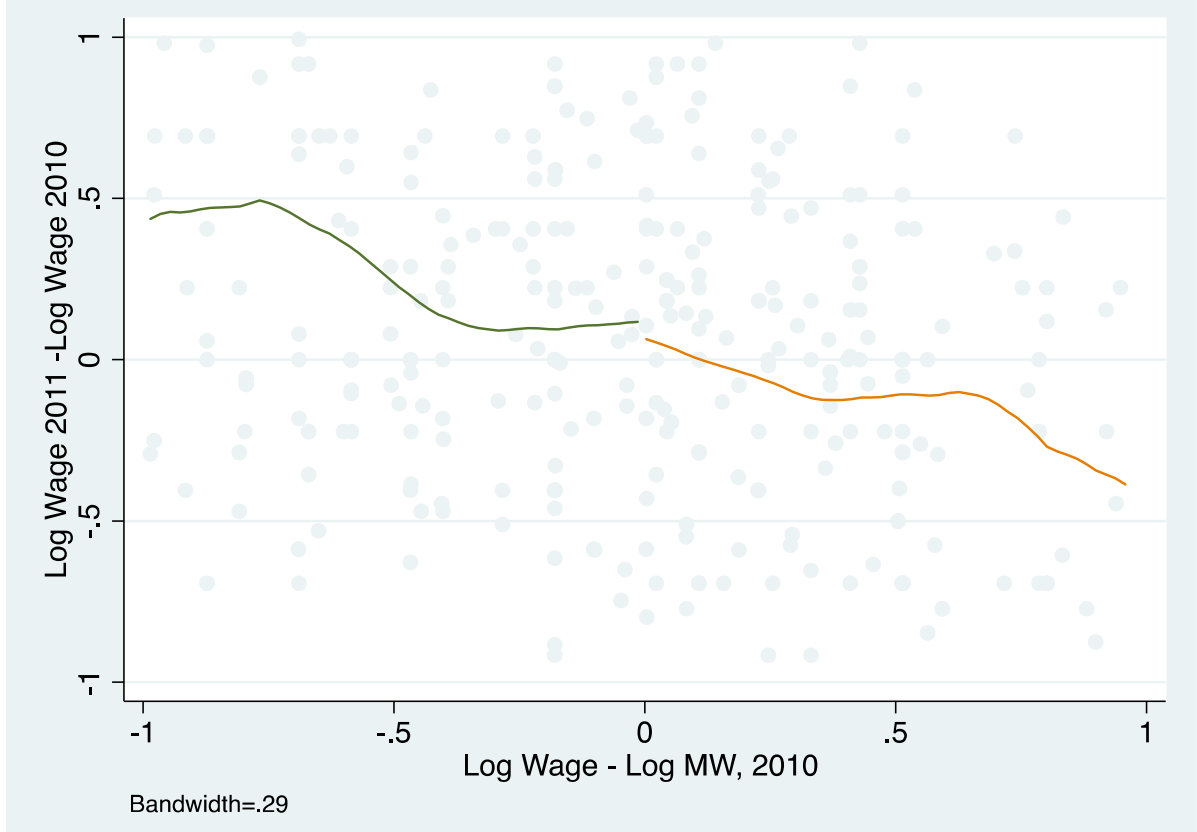

Notes: Estimated discontinuity $=.017$, standard error $=.215$. 
Figure 8: Employment Effect: graphical representation of regression discontinuity estimate of impact on the probability that a full-time private employee in 2010 remains a full-time employee in 2011

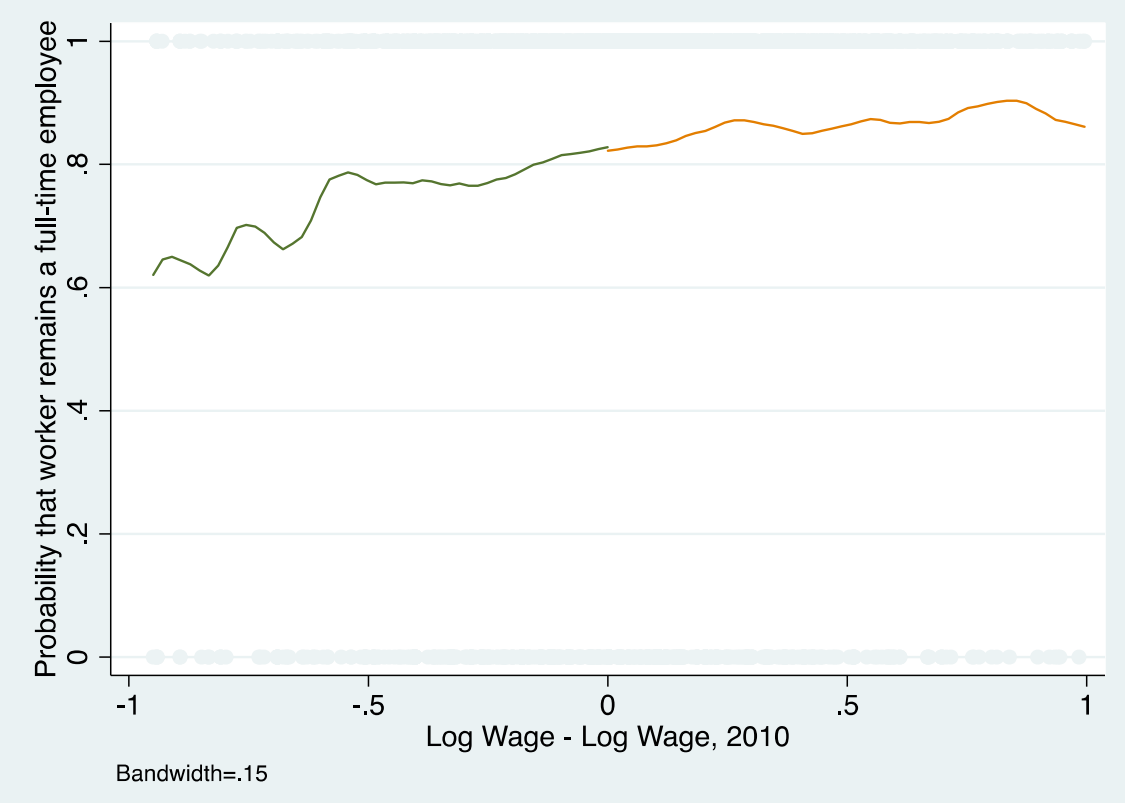

Notes: Estimated discontinuity $=.019$, standard error $=.048$.

Figure A1: Density of the assignment variable (Log Wage - Log MW, 2010)

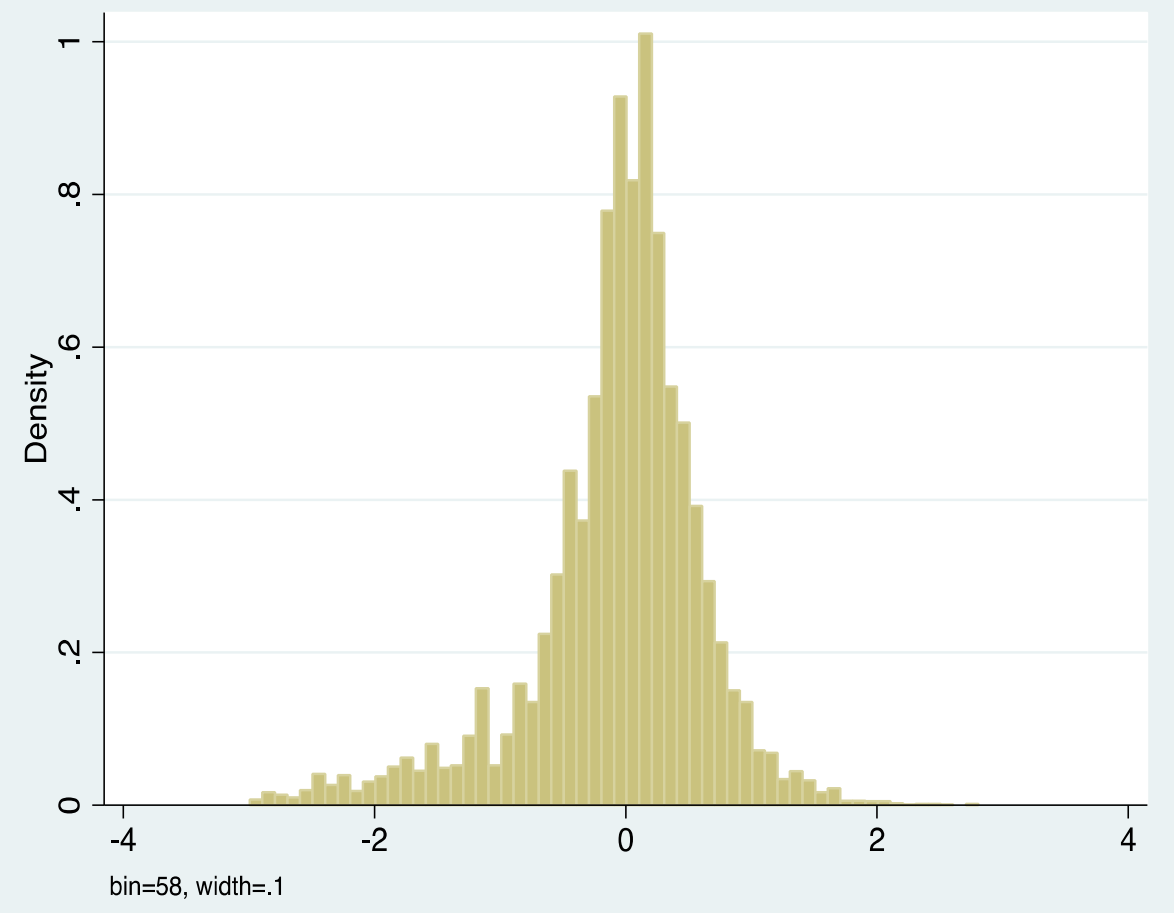


42

Figure A2: Graphical representation of regression discontinuity estimates of the effect of minimum wage enforcement on the probability of receiving mandated non-wage benefits in 2011 for full time private sector employees.
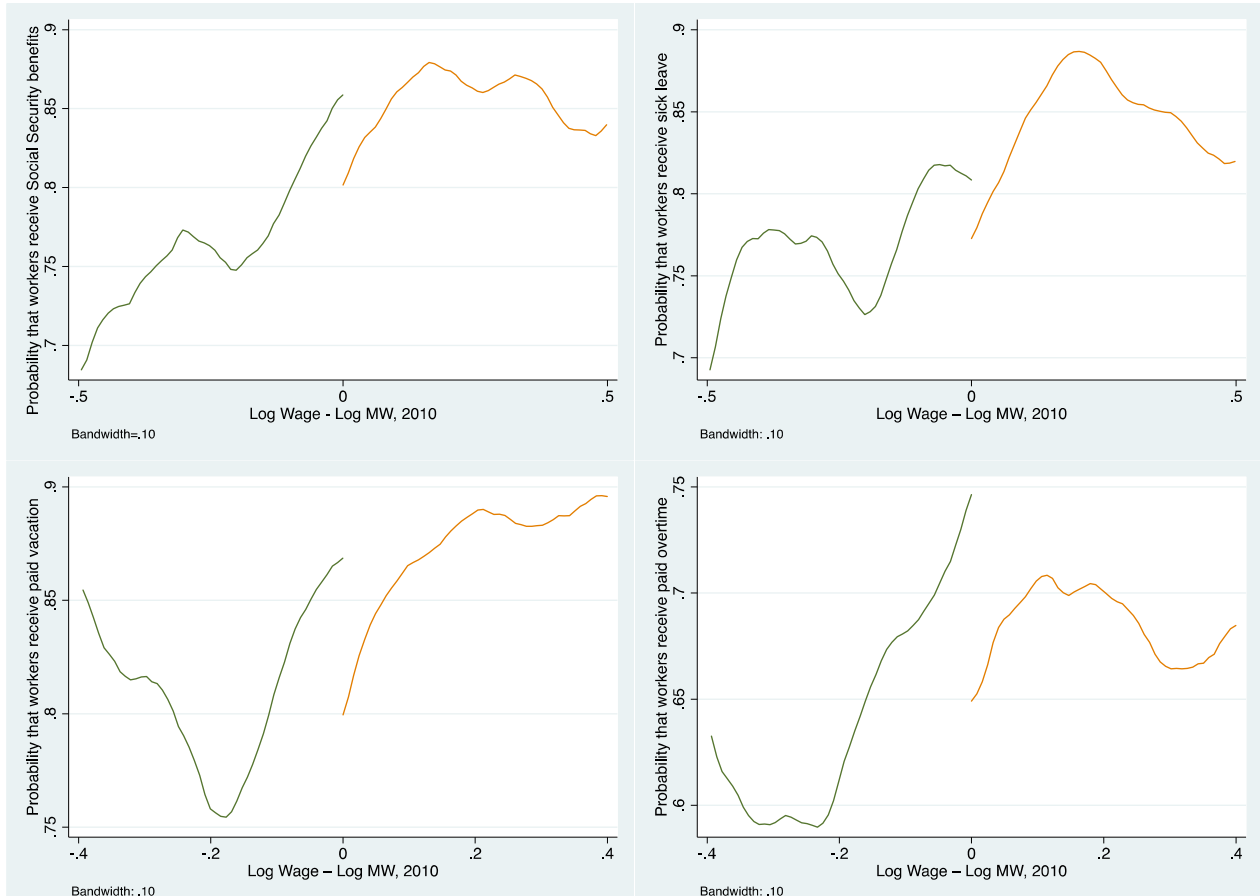

Bandwidth: .10 
Table 1: Number of labor inspections, 2005-2011

\begin{tabular}{|c|c|c|c|c|c|c|c|}
\hline & 2005 & 2006 & 2007 & 2008 & 2009 & 2010 & 2011 \\
\hline Total First Inspections & 6,717 & 5,888 & 6,815 & 8,673 & 7,415 & 9,512 & 10,521 \\
\hline Full inspections (Not Targeted) & 6,717 & 5,888 & 6,815 & 8,673 & 7,415 & 4,313 & 2,115 \\
\hline Minimum Wage targeted (CSM) & 0 & 0 & 0 & 0 & 0 & 5,199 & 8,406 \\
\hline Total Second Inspections & 4,525 & 4,080 & 3,015 & 3,652 & 4,061 & 4,493 & 7,028 \\
\hline Full inspections (Not Targeted) & 4,525 & 4,080 & 3,015 & 3,652 & 4,061 & 3,148 & 1,863 \\
\hline Minimum Wage Targeted (CSM) & 0 & 0 & 0 & 0 & 0 & 1,345 & 5,165 \\
\hline Total Inspections & 11,242 & 9,968 & 9,830 & 12,325 & 11,476 & 14,005 & 17,549 \\
\hline
\end{tabular}

Source: Costa Rican Ministry of Labor. 
Table 2: Descriptive statistics - Percent of full-time, private sector workers below, at and above the minimum wage for different sub-samples of workers, 2010.

\begin{tabular}{|c|c|c|c|c|c|c|c|c|c|}
\hline \multirow[b]{2}{*}{ Variables } & \multicolumn{3}{|c|}{ Full sample } & \multicolumn{3}{|c|}{ Within $15 \%$ of MW } & \multicolumn{3}{|c|}{ Within $10 \%$ of MW } \\
\hline & $\begin{array}{c}\text { Below } \\
95 \% \text { of } \\
\text { MW }\end{array}$ & $\begin{array}{c}\text { At } \\
\mathrm{MW}^{1}\end{array}$ & $\begin{array}{c}\text { Above } \\
105 \% \\
\text { of } \mathrm{MW} \\
\end{array}$ & $\begin{array}{c}\text { Below } \\
95 \% \text { of } \\
\text { MW }\end{array}$ & $\begin{array}{c}\text { At } \\
\mathrm{MW}^{1}\end{array}$ & $\begin{array}{c}\text { Above } \\
105 \% \\
\text { of } \mathrm{MW}\end{array}$ & $\begin{array}{c}\text { Below } \\
95 \% \text { of } \\
\text { MW }\end{array}$ & $\begin{array}{c}\text { At } \\
\mathrm{MW}^{1}\end{array}$ & $\begin{array}{c}\text { Above } \\
105 \% \\
\text { of } \mathrm{MW}\end{array}$ \\
\hline \multicolumn{10}{|l|}{ Gender } \\
\hline Female & 36.4 & 10.9 & 52.6 & 27.9 & 30.0 & 42.2 & 13.7 & 52.8 & 33.6 \\
\hline Male & 30.3 & 11.4 & 58.3 & 28.9 & 35.6 & 35.5 & 16.9 & 56.1 & 27.0 \\
\hline \multicolumn{10}{|l|}{ Age } \\
\hline Youth (15-24 years old) & 45.9 & 11.7 & 42.5 & 30.5 & 31.3 & 38.2 & 14.3 & 56.0 & 29.7 \\
\hline 25 years and older & 27.9 & 11.2 & 61.0 & 28.0 & 34.8 & 37.3 & 16.5 & 54.9 & 28.6 \\
\hline \multicolumn{10}{|l|}{ Education } \\
\hline Primary/Secondary ( 1 to 12 years) & 34.8 & 12.1 & 53.1 & 29.3 & 34.0 & 36.7 & 16.9 & 55.6 & 27.4 \\
\hline University Education (13 to 21 years) & 19.7 & 7.6 & 72.8 & 24.5 & 35.0 & 40.5 & 10.9 & 52.0 & 37.1 \\
\hline \multicolumn{10}{|l|}{ Firm Size } \\
\hline Micro-Firms ( 1 to 5 workers) & 43.7 & 11.5 & 44.8 & 30.4 & 32.0 & 37.6 & 16.6 & 57.5 & 26.0 \\
\hline Small/Medium-Firms (6 to 99 workers) & 33.4 & 11.1 & 55.5 & 31.2 & 32.0 & 36.8 & 17.7 & 52.5 & 29.8 \\
\hline Large-Firms (100 plus workers) & 22.8 & 11.5 & 65.7 & 23.1 & 38.5 & 38.4 & 13.2 & 57.9 & 28.9 \\
\hline \multicolumn{10}{|l|}{ Industry } \\
\hline Agriculture & 38.3 & 13.2 & 48.4 & 27.7 & 34.0 & 38.3 & 12.0 & 55.2 & 32.8 \\
\hline Manufacturing & 30.0 & 12.2 & 57.8 & 26.8 & 39.1 & 34.0 & 13.4 & 57.6 & 29.0 \\
\hline Service & 38.3 & 9.2 & 52.5 & 27.4 & 32.9 & 39.8 & 5.2 & 67.7 & 27.1 \\
\hline Construction & 19.4 & 11.0 & 69.6 & 14.8 & 36.0 & 49.2 & 3.7 & 63.5 & 32.8 \\
\hline Commerce & 34.6 & 10.4 & 54.9 & 30.1 & 29.4 & 40.5 & 20.6 & 49.3 & 30.1 \\
\hline Transportation & 22.1 & 8.4 & 69.5 & 24.2 & 36.4 & 39.4 & 21.5 & 52.8 & 25.7 \\
\hline Finance & 29.8 & 12.8 & 57.4 & 39.4 & 36.0 & 24.6 & 23.1 & 58.1 & 18.8 \\
\hline
\end{tabular}

Note: ${ }^{1}$ Percent of workers earning within $5 \%$ of the minimum wage. 
Table 3: Change between 2010 and 2011 in the log of mean monthly earnings, for those who were full-time private sector employees in both July 2010 and July 2011; comparing those who earned below the minimum wage in 2010 with those who earned above the minimum wage in 2012

\begin{tabular}{|lccc|}
\hline & $\begin{array}{c}\text { Within } \\
\mathbf{1 \%} \text { of } \\
\text { MW in } \\
\mathbf{2 0 1 0}\end{array}$ & $\begin{array}{c}\text { Within } \\
\mathbf{5 \%} \text { of } \\
\mathbf{M W} \text { in } \\
\mathbf{2 0 1 0}\end{array}$ & $\begin{array}{c}\text { Within } \\
\mathbf{1 0 \%} \text { of } \\
\mathbf{M W} \text { in } \\
\mathbf{2 0 1 0}\end{array}$ \\
$\begin{array}{l}\text { Change in log earnings (2010- } \\
\text { 2011) for worker who were below } \\
\text { the MW in 2010 }\end{array}$ & 0.15 & 0.164 & 0.142 \\
$\begin{array}{l}\text { (Standard deviation) } \\
\text { Change in log earnings (2010- }\end{array}$ & $(0.268)$ & $(0.269)$ & $(0.278)$ \\
$\begin{array}{l}\text { 2011) for worker who were at or } \\
\text { above the MW in 2010 }\end{array}$ & 0.051 & 0.066 & 0.052 \\
$\quad$ (Standard deviation) & $(0.385)$ & $(0.317)$ & $(0.374)$ \\
& & & \\
\hline & 0.099 & $0.098^{* * *}$ & $0.090^{* * *}$ \\
\hline
\end{tabular}

Notes: For those who were full-time private sector employees in both July 2010 and July 2011; $* * *$ significant at $1 \%$ 
Table 4: Estimates of the effect of the Campaign on wages (not including covariates)

\begin{tabular}{l|ccc|ccc|c}
\hline \hline & \multicolumn{3}{c|}{ Non-parametric: Rectangular kernel } & \multicolumn{2}{c|}{ Non-parametric: Triangular kernel } & Polynomial \\
\hline \multirow{2}{*}{ Bandwidth } & $(+/-0.10)$ & $(+/-0.15)$ & $(+/-0.21)$ & $(+/-0.10)$ & $(+/-0.15)$ & $(+/-0.21)$ & \multicolumn{2}{c}{ (5th order) } \\
& $(1)$ & $(2)$ & $(3)$ & $(4)$ & $(5)$ & $(6)$ & $(7)$ \\
\hline RD effect & $0.0855^{*}$ & $0.101^{* *}$ & $0.0814^{* *}$ & 0.073 & $0.095^{* *}$ & $0.088^{* *}$ & $0.116^{* *}$ \\
& $(0.051)$ & $(0.043)$ & $(0.037)$ & $(0.055)$ & $(0.046)$ & $(0.041)$ & $(0.045)$ \\
& & & & & & -- & 0.2 \\
$\mathrm{R}^{2}$ & 0.033 & 0.018 & 0.025 & -- & -- & -- & 2015 \\
$\mathrm{~N}$ & 428 & 680 & 938 & -- & -- & -- & \\
\hline
\end{tabular}

Notes: ***Indicate statistical significance at the $1 \%$ level. **For the $5 \%$ level. *For the $10 \%$ level. Standard errors are shown in parentheses. For those who were employed full-time in the private sector in 2010 and remained fulltime private sector employees in 2011. 
Table 5: Estimates of the effect of the Campaign on wages (including covariates)

\begin{tabular}{|c|c|c|c|c|c|c|c|}
\hline \multirow[b]{2}{*}{ Bandwidth } & \multicolumn{3}{|c|}{ Non-parametric: Rectangular kernel } & \multicolumn{3}{|c|}{ Non-parametric: Triangular kernel } & \multirow{2}{*}{$\frac{\text { Polynomial }}{\text { (5th order) }}$} \\
\hline & $(+/-0.10)$ & $(+/-0.15)$ & $(+/-0.21)$ & $(+/-0.10)$ & $(+/-0.15)$ & $(+/-0.21)$ & \\
\hline \multirow[t]{2}{*}{ RD effect } & 0.055 & $0.077 *$ & 0.060 & 0.073 & $0.095 * *$ & $0.088 * *$ & $0.100 * *$ \\
\hline & $(0.055)$ & $(0.043)$ & $(0.037)$ & $(0.055)$ & $(0.046)$ & $(0.041)$ & $(0.044)$ \\
\hline \multirow[t]{2}{*}{ Age } & 0.000 & 0.000 & 0.000 & 0.471 & -0.175 & 0.414 & 0.000 \\
\hline & $(0.001)$ & $(0.001)$ & $(0.001)$ & $(2.274)$ & $(1.916)$ & $(1.700)$ & $(0.001)$ \\
\hline \multirow[t]{2}{*}{ Sex } & $-0.083^{*}$ & $-0.071 * *$ & $-0.064 * *$ & $0.216^{* * *}$ & $0.209 * * *$ & $0.174 * * *$ & $0.049^{* *}$ \\
\hline & $(0.045)$ & $(0.029)$ & -0.025 & $(0.082)$ & $(0.068)$ & $(0.060)$ & $(0.020)$ \\
\hline \multirow[t]{2}{*}{ Years of Education } & $0.015 * * *$ & $0.011 * * *$ & $0.009 * * *$ & 0.928 & $1.015^{*}$ & $0.877^{*}$ & $0.005^{*}$ \\
\hline & $(0.005)$ & $(0.004)$ & $(0.003)$ & $(0.657)$ & $(0.574)$ & $(0.519)$ & $(0.003)$ \\
\hline \multirow[t]{2}{*}{ Small firm } & -0.002 & 0.004 & -0.008 & -0.087 & -0.081 & $-0.081^{*}$ & $-0.062 * * *$ \\
\hline & $(0.047)$ & $(0.031)$ & $(0.026)$ & $(0.061)$ & $(0.052)$ & $(0.047)$ & $(0.021)$ \\
\hline \multirow[t]{2}{*}{ Union Membership } & $0.093 *$ & $0.125 * * *$ & $0.120 * * *$ & 0.041 & 0.051 & 0.058 & $0.141 * * *$ \\
\hline & $(0.052)$ & $(0.041)$ & $(0.035)$ & $(0.058)$ & $(0.046)$ & $(0.040)$ & $(0.028)$ \\
\hline Industry Dummies & YES & YES & YES & YES & YES & YES & YES \\
\hline $\mathrm{R}^{2}$ & 0.128 & 0.078 & 0.062 & -- & -- & -- & 0.231 \\
\hline $\mathrm{N}$ & 428 & 680 & 911 & -- & -- & -- & 2,015 \\
\hline
\end{tabular}

Notes: $* * *$ Indicate statistical significance at the $1 \%$ level. **For the $5 \%$ level. *For the $10 \%$ level. Standard errors are shown in parentheses. For those who were employed full-time in the private sector in 2010 and remained full-time private sector employees in 2011. Regressions include 6 industry dummies: agriculture, commerce, finance, transportation, services and manufacturing. 
Table 6: For different groups: Estimates of the effect of the Campaign on wages

\begin{tabular}{|c|c|c|c|c|c|c|c|}
\hline \multirow[b]{2}{*}{ Bandwidth } & \multicolumn{3}{|c|}{ Non-parametric: Rectangular kernel } & \multicolumn{3}{|c|}{ Non-parametric: Triangular kernel } & \multirow{2}{*}{$\begin{array}{r}\text { Polynomia } \\
\text { (5th order) }\end{array}$} \\
\hline & $(+/-0.10)$ & $(+/-0.15)$ & $(+/-0.21)$ & $(+/-0.10)$ & $(+/-0.15)$ & $(+/-0.21)$ & \\
\hline \multirow{2}{*}{ Female } & $0.208^{*}$ & $0.230 * *$ & $0.161 *$ & 0.157 & $0.212^{*}$ & $0.209 * *$ & $0.272 * * *$ \\
\hline & $(0.123)$ & $(0.102)$ & $(0.087)$ & $(0.133)$ & $(0.110)$ & $(0.098)$ & $(0.101)$ \\
\hline \multirow{2}{*}{ Male } & 0.053 & 0.061 & 0.049 & 0.055 & 0.063 & 0.053 & 0.086 \\
\hline & $(0.059)$ & $(0.050)$ & $(0.043)$ & $(0.064)$ & $(0.053)$ & $(0.047)$ & $(0.054)$ \\
\hline \multirow{2}{*}{ Youth (15-24 years old) } & $0.181^{*}$ & 0.128 & 0.107 & 0.174 & $0.156^{*}$ & $0.139 *$ & $0.157 *$ \\
\hline & $(0.100)$ & $(0.080)$ & $(0.069)$ & $(0.114)$ & $(0.088)$ & $(0.077)$ & $(0.092)$ \\
\hline \multirow{2}{*}{25 years and older } & 0.057 & $0.0943 *$ & 0.064 & 0.040 & 0.075 & 0.073 & $0.113 * *$ \\
\hline & $(0.059)$ & $(0.050)$ & $(0.045)$ & $(0.064)$ & $(0.054)$ & $(0.048)$ & $(0.053)$ \\
\hline \multirow{2}{*}{ Primary/Secondary Ed. (1 to 12 years) } & 0.074 & $0.101 * *$ & $0.0758^{*}$ & 0.063 & $0.091 *$ & $0.086 * *$ & $0.122 * *$ \\
\hline & $(0.053)$ & $(0.045)$ & $(0.040)$ & $(0.057)$ & $(0.048)$ & $(0.042)$ & $(0.049)$ \\
\hline \multirow{2}{*}{ University Education } & 0.349 & 0.286 & 0.186 & 0.381 & 0.360 & 0.278 & $0.320^{*}$ \\
\hline & $(0.250)$ & $(0.187)$ & $(0.161)$ & $(0.303)$ & $(0.231)$ & $(0.188)$ & $(0.168)$ \\
\hline \multirow{2}{*}{ Micro-Firms ( 1 to 5 workers) } & 0.251 & 0.234 & 0.179 & 0.216 & 0.249 & 0.221 & $0.285^{*}$ \\
\hline & $(0.179)$ & $(0.142)$ & $(0.123)$ & $(0.193)$ & $(0.158)$ & $(0.140)$ & $(0.152)$ \\
\hline \multirow{2}{*}{ Small/Medium-Firms (6 to 99 workers) } & $0.177 * *$ & $0.169 * * *$ & $0.162 * * *$ & $0.181 * *$ & $0.179 * * *$ & $0.171^{* * *}$ & $0.210 * * *$ \\
\hline & $(0.073)$ & $(0.063)$ & $(0.054)$ & $(0.081)$ & $(0.067)$ & $(0.060)$ & $(0.066)$ \\
\hline Large-Firms (100 plus workers) & $\begin{array}{c}0.085 \\
(0.089)\end{array}$ & $\begin{array}{c}0.127 \\
(0.077)\end{array}$ & $\begin{array}{c}0.078 \\
(0.067)\end{array}$ & $\begin{array}{c}0.059 \\
(0.098)\end{array}$ & $\begin{array}{c}0.093 \\
(0.081)\end{array}$ & $\begin{array}{c}0.086 \\
(0.071)\end{array}$ & $\begin{array}{c}0.122 \\
(0.080)\end{array}$ \\
\hline
\end{tabular}

Notes: ***Indicate statistical significance at the $1 \%$ level. **For the $5 \%$ level. *For the $10 \%$ level. Standard errors are shown in parentheses. No covariates. For those who were employed full-time in the private sector in 2010 and remained full-time private sector employees in 2011. 
Table 7: Estimates of the effect of the Campaign on self-employed workers' wages (Placebo Test)

\begin{tabular}{l|ccc|ccc|c}
\hline \hline & \multicolumn{2}{|c|}{ Non-parametric: Rectangular kernel } & \multicolumn{2}{c|}{ Non-parametric: Triangular kernel } & Polynomial \\
\hline Bandwidth & $(+/-0.10)$ & $(+/-0.15)$ & $(+/-0.21)$ & $(+/-0.10)$ & $(+/-0.15)$ & $(+/-0.21)$ & (5th order) \\
\hline RD effect & -0.056 & -0.015 & 0.043 & 0.282 & 0.026 & 0.014 & -0.031 \\
& $(0.341)$ & $(0.276)$ & $(0.232)$ & $(0.371)$ & $(0.287)$ & $(0.235)$ & $(0.205)$ \\
& & & & & & & \\
$\mathrm{R}^{2}$ & 0.021 & 0.02 & 0.027 & -- & -- & -- & 0.315 \\
$\mathrm{~N}$ & 57 & 95 & 135 & -- & -- & -- & 502 \\
\hline
\end{tabular}

Notes: ***Indicate statistical significance at the $1 \%$ level. ${ }^{*}$ For the $5 \%$ level. *For the $10 \%$ level. Standard errors are shown in parentheses. Regressions not including covariates. 
Table 8: Estimates of the effect of the Campaign on the probability of remaining employed as a full-time private sector employee

\begin{tabular}{l|ccc|ccc|c}
\hline \hline & \multicolumn{2}{|c|}{ Non-parametric: Rectangular kernel } & \multicolumn{2}{|c|}{ Non-parametric: Triangular kernel } & Polynomial \\
\hline Bandwidth & $(+/-0.10)$ & $(+/-0.15)$ & $(+/-0.21)$ & $(+/-0.10)$ & $(+/-0.15)$ & $(+/-0.21)$ & (5th order) \\
\hline
\end{tabular}

\begin{tabular}{|c|c|c|c|c|c|c|c|}
\hline \multicolumn{8}{|c|}{ Not including covariates } \\
\hline RD effect & $\begin{array}{c}0.031 \\
(0.056)\end{array}$ & $\begin{array}{c}0.019 \\
(0.048)\end{array}$ & $\begin{array}{l}0.0231 \\
(0.042)\end{array}$ & $\begin{array}{c}0.069 \\
(0.058)\end{array}$ & $\begin{array}{c}0.030 \\
(0.050)\end{array}$ & $\begin{array}{c}0.029 \\
(0.045)\end{array}$ & $\begin{array}{c}0.036 \\
(0.046)\end{array}$ \\
\hline $\mathrm{R}^{2}$ & 0.001 & 0.001 & 0.002 & -- & -- & -- & 0.022 \\
\hline $\mathrm{N}$ & 589 & 944 & 1,259 & -- & -- & -- & 2,773 \\
\hline \multicolumn{8}{|c|}{ Including covariates } \\
\hline $\mathrm{RD}$ effect & $\begin{array}{c}0.005 \\
(0.050)\end{array}$ & $\begin{array}{c}0.013 \\
(0.050)\end{array}$ & $\begin{array}{l}0.0143 \\
(0.041)\end{array}$ & $\begin{array}{c}0.069 \\
(0.058)\end{array}$ & $\begin{array}{c}0.030 \\
(0.050)\end{array}$ & $\begin{array}{c}0.029 \\
(0.045)\end{array}$ & $\begin{array}{c}0.028 \\
(0.040)\end{array}$ \\
\hline
\end{tabular}

$\begin{array}{lccccccc}\mathrm{R}^{2} & 0.086 & 0.063 & 0.065 & -- & -- & -- & 0.08 \\ \mathrm{~N} & 589 & 944 & 1,259 & -- & -- & -- & 2,773\end{array}$

Notes: $* * *$ Indicate statistical significance at the $1 \%$ level. $* *$ For the $5 \%$ level. *For the $10 \%$ level. Standard errors are shown in parentheses. 
Table 9: Estimates of the effect the Campaign on the probability of remaining employed for part-time workers

\begin{tabular}{|c|c|c|c|c|c|c|c|}
\hline \multirow[b]{2}{*}{ Bandwidth } & \multicolumn{3}{|c|}{ Non-parametric: Rectangular kernel } & \multicolumn{3}{|c|}{ Non-parametric: Triangular kernel ${ }^{1}$} & \multirow{2}{*}{$\frac{\text { Polynomial }}{\text { (5th order) }}$} \\
\hline & $(+/-0.10)$ & $(+/-0.15)$ & $(+/-0.21)$ & $(+/-0.10)$ & $(+/-0.15)$ & $(+/-0.21)$ & \\
\hline \multicolumn{8}{|c|}{ Not Including Covariates } \\
\hline $\mathrm{RD}$ effect & $\begin{array}{c}-0.091 \\
(0.140)\end{array}$ & $\begin{array}{l}-0.110 \\
(0.119)\end{array}$ & $\begin{array}{c}-0.054 \\
(0.103)\end{array}$ & $\begin{array}{l}0.092 \\
(0.156)\end{array}$ & $\begin{array}{l}0.084 \\
(0.127)\end{array}$ & $\begin{array}{l}0.068 \\
(0.114)\end{array}$ & $\begin{array}{r}0.018 \\
-0.097\end{array}$ \\
\hline $\mathrm{R}^{2}$ & 126 & 202 & 253 & -- & -- & -- & 940 \\
\hline $\mathrm{N}$ & 0.005 & 0.014 & 0.007 & -- & -- & -- & 0.012 \\
\hline \multicolumn{8}{|c|}{ Including Covariates } \\
\hline $\mathrm{RD}$ effect & $\begin{array}{l}-0.104 \\
(0.139)\end{array}$ & $\begin{array}{l}-0.068 \\
(0.114)\end{array}$ & $\begin{array}{l}-0.021 \\
(0.097)\end{array}$ & $\begin{array}{l}0.092 \\
(0.156)\end{array}$ & $\begin{array}{l}0.084 \\
(0.127)\end{array}$ & $\begin{array}{l}0.068 \\
(0.114)\end{array}$ & $\begin{array}{r}0.005 \\
-0.095\end{array}$ \\
\hline $\mathrm{R}^{2}$ & 126 & 202 & 253 & -- & -- & -- & 940 \\
\hline $\mathrm{N}$ & 0.250 & 0.238 & 0.221 & -- & -- & -- & 0.151 \\
\hline
\end{tabular}

Notes: ${ }^{1}$ The bandwidths for the non-parametric triangular kernel estimates were chosen based on the technique described in Imbens and Kalyanaraman (2009). ***Indicate statistical significance at the $1 \%$ level. **For the 5\% level.

*For the $10 \%$ level. Standard errors are shown in parentheses. 
Table 10: Estimates of the effect of the Campaign on the probability of receiving non-wage benefits

\begin{tabular}{|c|c|c|c|c|c|c|c|}
\hline \multirow[b]{2}{*}{ Bandwidth } & \multicolumn{3}{|c|}{$\begin{array}{l}\text { Non-parametric: Rectangular } \\
\text { kernel }\end{array}$} & \multicolumn{3}{|c|}{$\begin{array}{c}\text { Non-parametric: Triangular } \\
\text { kernel }^{1}\end{array}$} & \multirow{2}{*}{$\frac{\text { Polynomia }}{\text { (5th order) }}$} \\
\hline & $(+/-0.10)$ & $(+/-0.15)$ & $(+/-0.21)$ & $(+/-0.10)$ & $(+/-0.15)$ & $(+/-0.21)$ & \\
\hline Social Security & $\begin{array}{l}0.103 * \\
(0.059)\end{array}$ & $\begin{array}{c}0.108 * * \\
(0.053)\end{array}$ & $\begin{array}{l}0.078 * \\
(0.045)\end{array}$ & $\begin{array}{c}0.137 * * \\
(0.063)\end{array}$ & $\begin{array}{c}0.111^{* *} \\
(0.054)\end{array}$ & $\begin{array}{c}0.102 * * \\
(0.049)\end{array}$ & $\begin{array}{c}0.058 \\
(0.044)\end{array}$ \\
\hline Paid Sick leave & $\begin{array}{c}0.036 \\
(0.067)\end{array}$ & $\begin{array}{c}0.061 \\
(0.058)\end{array}$ & $\begin{array}{l}0.090 * \\
(0.050)\end{array}$ & $\begin{array}{l}0.0423 \\
(0.074)\end{array}$ & $\begin{array}{l}0.0492 \\
(0.061)\end{array}$ & $\begin{array}{c}0.072 \\
(0.054)\end{array}$ & $\begin{array}{c}0.045 \\
(0.046)\end{array}$ \\
\hline Paid Vacation & $\begin{array}{c}0.129 * * \\
(0.061)\end{array}$ & $\begin{array}{l}0.111^{* *} \\
(0.052)\end{array}$ & $\begin{array}{r}0.114 * * \\
(0.045)\end{array}$ & $\begin{array}{c}0.149^{* *} \\
(0.066)\end{array}$ & $\begin{array}{c}0.123^{* *} \\
(0.055)\end{array}$ & $\begin{array}{l}0.121^{* *} \\
(0.049)\end{array}$ & $\begin{array}{c}0.057 \\
(0.043)\end{array}$ \\
\hline Paid Overtime & $\begin{array}{c}0.216 * * * \\
(0.072)\end{array}$ & $\begin{array}{l}0.109^{*} \\
(0.063)\end{array}$ & $\begin{array}{l}0.107 * \\
(0.055)\end{array}$ & $\begin{array}{c}0.237 * * * \\
(0.074)\end{array}$ & $\begin{array}{c}0.168 * * * \\
(0.064)\end{array}$ & $\begin{array}{c}0.133 * * \\
(0.058)\end{array}$ & $\begin{array}{r}0.103 * * \\
(0.052)\end{array}$ \\
\hline Training & $\begin{array}{l}0.182^{*} \\
(0.102)\end{array}$ & $\begin{array}{l}0.161^{*} \\
(0.086)\end{array}$ & $\begin{array}{l}0.123^{*} \\
(0.074)\end{array}$ & $\begin{array}{l}0.151^{*} \\
(0.082)\end{array}$ & $\begin{array}{l}0.114^{*} \\
(0.067)\end{array}$ & $\begin{array}{l}0.101^{*} \\
(0.060)\end{array}$ & $\begin{array}{l}0.043 \\
(0.048)\end{array}$ \\
\hline $\mathrm{N}$ & 470 & 745 & 936 & -- & -- & -- & 2,319 \\
\hline
\end{tabular}

Notes: ${ }^{1}$ The bandwidths for the non-parametric triangular kernel estimates were chosen based on the technique described in Imbens and Kalyanaraman (2009). ***Indicate statistical significance at the $1 \%$ level. **For the $5 \%$ level. *For the $10 \%$ level. Standard errors are shown in parentheses.

For full-time private sector employees. 
Table A1: Results of initial targeted minimum wage inspections : August 1, 2010 to July 31, 2011

\begin{tabular}{|c|c|c|c|c|c|c|}
\hline \multirow[b]{2}{*}{ Type of Firm } & \multicolumn{3}{|c|}{ Firms inspected } & \multicolumn{3}{|c|}{ Employees } \\
\hline & Total & $\begin{array}{l}\text { Minimum } \\
\text { wage } \\
\text { violation } \\
\text { found }\end{array}$ & $\begin{array}{l}\% \text { of firms } \\
\text { with MW } \\
\text { violations }\end{array}$ & $\begin{array}{l}\text { Total private } \\
\text { sector } \\
\text { employees }\end{array}$ & $\begin{array}{l}\text { Employees } \\
\text { in inspected } \\
\text { firms }\end{array}$ & $\begin{array}{l}\% \text { of total } \\
\text { private } \\
\text { sector } \\
\text { employees } \\
\text { inspected }\end{array}$ \\
\hline
\end{tabular}

$\begin{array}{lllllll}\text { Total firms and employees } & 9,135 & 3,861 & 42.3 & 1,030,612 & 72,982 & 7.1\end{array}$

\section{By firm size}

\begin{tabular}{|c|c|c|c|c|c|c|}
\hline Microfirms (1-5 workers) & 6979 & 77.6 & 43.2 & 234992 & 13517 & 5.8 \\
\hline Small firms (6-30 workers) & 1799 & 19.4 & 41.9 & 349044 & 18992 & 5.5 \\
\hline Medium sized firms (31-100 workers) & 256 & 2.3 & 34.3 & 155067 & 12221 & 7.9 \\
\hline Large firms (more than 100 workers) & 101 & 0.8 & 29.3 & 291510 & 28253 & 9.7 \\
\hline \multicolumn{7}{|l|}{ y sector } \\
\hline Agriculture & 460 & 5.2 & 44.0 & 183592 & 3974 & 2.2 \\
\hline Manufacturing & 1008 & 11.2 & 42.8 & 173385 & 21671 & 12.5 \\
\hline Construction & 133 & 0.8 & 23.1 & 87657 & 1962 & 2.2 \\
\hline Commerce & 6267 & 71.2 & 43.8 & 293132 & 34932 & 11.9 \\
\hline Transport & 124 & 0.8 & 24.8 & 78083 & 1274 & 1.6 \\
\hline Services & 1143 & 10.8 & 36.6 & 214763 & 9169 & 4.3 \\
\hline
\end{tabular}

Notes: 1. Total employees in private sector firms in July of 2011 according to the National Household Surveys (Encuestas Nacional de Hogares). Sources: Ministry of Labor and National Institute of Statistics and Census, National Household Surveys. 
TableA2: Results of second inspections: 2010-2011

\begin{tabular}{|lcccc|}
\hline & $\mathbf{2 0 0 5}$ & $\mathbf{2 0 0 7}$ & $\mathbf{2 0 1 0}$ & $\begin{array}{c}\mathbf{2 0 1 1} \text { (Jan. 1 } \\
\text { to June 30) }\end{array}$ \\
$\begin{array}{l}\text { Total number of second } \\
\text { visits }\end{array}$ & 4,351 & 3,015 & 4,493 & 1,927 \\
\hline $\begin{array}{l}\text { Second visits (full } \\
\text { inspections - not targeted) }\end{array}$ & 4,351 & 3,015 & 3,148 & 706 \\
$\begin{array}{l}\text { Complied } \\
\text { Not complied }\end{array}$ & 63.3 & 63.5 & - & 77.4 \\
Not applicable & 19.7 & 19.4 & - & 13.2 \\
\hline $\begin{array}{l}\text { Second visits (minimum } \\
\text { wage targeted - CSM) }\end{array}$ & 17.1 & 17.1 & - & 8.3 \\
\hline $\begin{array}{l}\text { Complied } \\
\text { Not complied }\end{array}$ & 0 & 0 & 1,345 & 1,221 \\
Not applicable & 0 & 0 & 80.4 & 74.7 \\
\hline Ne: & 0 & 0 & 8.2 & 10.7 \\
\hline
\end{tabular}

Note: not applicable implies that either the worker or firm was no longer present.

Source: Ministry of Labor. 
Table A3: Estimates of the effect of the Campaign on wages by industry type

\begin{tabular}{|c|c|c|c|}
\hline & \multicolumn{3}{|c|}{ Non-parametric: Rectangular kernel } \\
\hline Bandwidth & $(+/-0.10)$ & $(+/-0.15)$ & $(+/-0.21)$ \\
\hline Commerce & $\begin{array}{c}-0.053 \\
(0.064)\end{array}$ & $\begin{array}{c}-0.021 \\
(0.058)\end{array}$ & $\begin{array}{c}0.019 \\
(0.055)\end{array}$ \\
\hline $\begin{array}{l}\mathrm{N} \\
\mathrm{R}^{2}\end{array}$ & $\begin{array}{c}119 \\
0.033\end{array}$ & $\begin{array}{c}196 \\
0.025\end{array}$ & $\begin{array}{c}263 \\
0.009\end{array}$ \\
\hline Finance & $\begin{array}{c}0.127 \\
(0.148)\end{array}$ & $\begin{array}{l}0.191 * \\
(0.099)\end{array}$ & $\begin{array}{c}0.086 \\
(0.094)\end{array}$ \\
\hline $\mathrm{N}$ & 43 & 64 & 84 \\
\hline $\mathrm{R}^{2}$ & 0.059 & 0.039 & 0.022 \\
\hline Construction & $\begin{array}{c}0.218 \\
(0.439)\end{array}$ & $\begin{array}{c}0.578 \\
(0.440)\end{array}$ & $\begin{array}{c}0.373 \\
(0.380)\end{array}$ \\
\hline $\mathrm{N}$ & 23 & 41 & 57 \\
\hline $\mathrm{R}^{2}$ & 0.168 & 0.038 & 0.042 \\
\hline Manufacturing & $\begin{array}{c}0.108 \\
(0.128)\end{array}$ & $\begin{array}{c}0.17 \\
(0.111)\end{array}$ & $\begin{array}{c}0.11 \\
(0.097)\end{array}$ \\
\hline $\mathrm{N}$ & 71 & 99 & 143 \\
\hline $\mathrm{R}^{2}$ & 0.109 & 0.133 & 0.107 \\
\hline Services & $\begin{array}{c}0.009 \\
(0.200)\end{array}$ & $\begin{array}{c}0.067 \\
(0.164)\end{array}$ & $\begin{array}{c}0.086 \\
(0.142)\end{array}$ \\
\hline $\begin{array}{l}\mathrm{N} \\
\mathrm{R}^{2}\end{array}$ & $\begin{array}{c}22 \\
0.091\end{array}$ & $\begin{array}{c}36 \\
0.160\end{array}$ & $\begin{array}{c}47 \\
0.163\end{array}$ \\
\hline Transportation & $\begin{array}{l}0.587^{*} \\
(0.283)\end{array}$ & $\begin{array}{c}0.402 \\
(0.245)\end{array}$ & $\begin{array}{c}0.154 \\
(0.217)\end{array}$ \\
\hline $\mathrm{N}$ & 26 & 37 & 54 \\
\hline $\mathrm{R}^{2}$ & 0.191 & 0.102 & 0.018 \\
\hline Agriculture & $\begin{array}{l}-0.032 \\
(0.072)\end{array}$ & $\begin{array}{l}-0.052 \\
(0.062)\end{array}$ & $\begin{array}{l}-0.030 \\
(0.058)\end{array}$ \\
\hline $\begin{array}{l}\mathrm{N} \\
\mathrm{R}^{2}\end{array}$ & $\begin{array}{c}130 \\
0.006\end{array}$ & $\begin{array}{c}210 \\
0.027\end{array}$ & $\begin{array}{c}257 \\
0.037\end{array}$ \\
\hline Domestic Service & $\begin{array}{c}-0.313 \\
(0.446)\end{array}$ & $\begin{array}{l}0.0919 \\
(0.387)\end{array}$ & $\begin{array}{l}-0.209 \\
(0.365)\end{array}$ \\
\hline $\mathrm{N}$ & 22 & 29 & 36 \\
\hline $\mathrm{R}^{2}$ & 0.101 & 0.031 & 0.127 \\
\hline
\end{tabular}

Notes: ***Indicate statistical significance at the $1 \%$ level. **For the $5 \%$ level. *For the $10 \%$ level. Standard errors are shown in parentheses. For full-time private sector employees. 
Table A4: Estimates of the effect of the Campaign on the probability of remaining employed as a full-time private sector employee (including covariates)

\begin{tabular}{|c|c|c|c|c|c|c|c|}
\hline \multirow[b]{2}{*}{ Bandwidth } & \multicolumn{3}{|c|}{ Non-parametric: Rectangular kernel } & \multicolumn{3}{|c|}{ Non-parametric: Triangular kernel } & \multirow{2}{*}{$\frac{\text { Polynomial }}{\text { (5th order) }}$} \\
\hline & $(+/-0.10)$ & $(+/-0.15)$ & $(+/-0.21)$ & $(+/-0.10)$ & $(+/-0.15)$ & $(+/-0.21)$ & \\
\hline RD effect & $\begin{array}{c}0.005 \\
(0.050)\end{array}$ & $\begin{array}{c}0.013 \\
(0.050)\end{array}$ & $\begin{array}{l}0.0143 \\
(0.041)\end{array}$ & $\begin{array}{c}0.069 \\
(0.058)\end{array}$ & $\begin{array}{c}0.030 \\
(0.050)\end{array}$ & $\begin{array}{c}0.029 \\
(0.045)\end{array}$ & $\begin{array}{c}0.028 \\
(0.040)\end{array}$ \\
\hline Age & $\begin{array}{c}0.001 \\
(0.000)\end{array}$ & $\begin{array}{c}0.000 \\
(0.000)\end{array}$ & $\begin{array}{c}-0.001 \\
(0.001)\end{array}$ & $\begin{array}{c}2.859 \\
(1.976)\end{array}$ & $\begin{array}{c}2.175 \\
(1.658)\end{array}$ & $\begin{array}{c}2.091 \\
(1.470)\end{array}$ & $\begin{array}{c}-0.001 \\
(0.000)\end{array}$ \\
\hline Sex & $\begin{array}{l}-0.077^{*} \\
(0.040)\end{array}$ & $\begin{array}{c}-0.092 * * * \\
(0.030)\end{array}$ & $\begin{array}{c}-0.108^{* * *} \\
(0.027)\end{array}$ & $\begin{array}{c}0.152^{* *} \\
(0.073)\end{array}$ & $\begin{array}{c}0.149 * * \\
(0.060)\end{array}$ & $\begin{array}{c}0.130^{* *} \\
(0.053)\end{array}$ & $\begin{array}{c}-0.088^{* * *} \\
(0.020)\end{array}$ \\
\hline Years of Education & $\begin{array}{c}0.000 \\
(0.010)\end{array}$ & $\begin{array}{c}-0.003 \\
0.000\end{array}$ & $\begin{array}{c}-0.003 \\
(0.003)\end{array}$ & $\begin{array}{c}0.672 \\
(0.552)\end{array}$ & $\begin{array}{c}0.556 \\
(0.484)\end{array}$ & $\begin{array}{c}0.506 \\
(0.438)\end{array}$ & $\begin{array}{l}0.001 \\
0.000\end{array}$ \\
\hline Small firm & $\begin{array}{c}-0.160 * * * \\
(0.050)\end{array}$ & $\begin{array}{c}-0.120^{* * * *} \\
(0.030)\end{array}$ & $\begin{array}{c}-0.114 * * * \\
(0.028)\end{array}$ & $\begin{array}{l}-0.011 \\
(0.065)\end{array}$ & $\begin{array}{l}-0.015 \\
(0.054)\end{array}$ & $\begin{array}{l}-0.0286 \\
(0.049)\end{array}$ & $\begin{array}{c}-0.133^{* * *} \\
(0.020)\end{array}$ \\
\hline Union Membership & $\begin{array}{c}0.140 * * * \\
(0.030)\end{array}$ & $\begin{array}{c}0.169 * * * \\
(0.020)\end{array}$ & $\begin{array}{c}0.163 * * * \\
(0.019)\end{array}$ & $\begin{array}{c}0.039 \\
(0.045)\end{array}$ & $\begin{array}{c}0.031 \\
(0.036)\end{array}$ & $\begin{array}{l}0.0312 \\
(0.032)\end{array}$ & $\begin{array}{c}0.123 * * * \\
(0.010)\end{array}$ \\
\hline Industry Dummies & YES & YES & YES & YES & YES & YES & YES \\
\hline R2 & 0.086 & 0.063 & 0.065 & -- & -- & -- & 0.08 \\
\hline $\mathrm{N}$ & 589 & 944 & 1,259 & -- & -- & -- & 2,773 \\
\hline
\end{tabular}

Notes: ***Indicate statistical significance at the $1 \%$ level. ${ }^{* *}$ For the $5 \%$ level. *For the $10 \%$ level. Standard errors are shown in parentheses. 
Table A5: For different groups: Estimates of the effect of the Campaign on the probability of remaining employed as a full-time private sector employee (not including covariates)

\begin{tabular}{|c|c|c|c|}
\hline \multirow[b]{2}{*}{ Bandwidth } & \multicolumn{3}{|c|}{$\begin{array}{c}\text { Non-parametric: Rectangular } \\
\text { kernel }\end{array}$} \\
\hline & $(+/-.10)$ & $(+/-.15)$ & $(+/-.21)$ \\
\hline Female & $\begin{array}{c}0.170 \\
(0.121)\end{array}$ & $\begin{array}{c}0.116 \\
(0.101)\end{array}$ & $\begin{array}{c}0.096 \\
(0.088)\end{array}$ \\
\hline Male & $\begin{array}{l}-0.006 \\
(0.063)\end{array}$ & $\begin{array}{l}-0.008 \\
(0.056)\end{array}$ & $\begin{array}{c}0.005 \\
(0.047)\end{array}$ \\
\hline Youth (15-24 years old) & $\begin{array}{l}0.133 \\
(0.130)\end{array}$ & $\begin{array}{c}0.100 \\
(0.109)\end{array}$ & $\begin{array}{l}0.0524 \\
(0.094)\end{array}$ \\
\hline 25 years and older & $\begin{array}{l}-0.006 \\
(0.061) \\
\end{array}$ & $\begin{array}{l}-0.009 \\
(0.053) \\
\end{array}$ & $\begin{array}{c}0.014 \\
(0.046) \\
\end{array}$ \\
\hline No-Education \& primary & $\begin{array}{c}0.015 \\
(0.059) \\
\end{array}$ & $\begin{array}{c}0.003 \\
(0.051) \\
\end{array}$ & $\begin{array}{c}0.002 \\
(0.044) \\
\end{array}$ \\
\hline No-Education & $\begin{array}{l}-0.355 \\
(0.273)\end{array}$ & $\begin{array}{l}0.038 \\
(0.287)\end{array}$ & $\begin{array}{c}-0.031 \\
(0.271)\end{array}$ \\
\hline Primary (1 to 6 years) & $\begin{array}{c}0.028 \\
(0.073)\end{array}$ & $\begin{array}{l}0.021 \\
(0.067)\end{array}$ & $\begin{array}{c}0.010 \\
(0.058)\end{array}$ \\
\hline Secondary ( 7 to 12 years) & $\begin{array}{l}0.020 \\
(0.104)\end{array}$ & $\begin{array}{l}-0.021 \\
(0.085)\end{array}$ & $\begin{array}{l}-0.013 \\
(0.072)\end{array}$ \\
\hline Tertiary (13 TO 21 years) & $\begin{array}{c}0.142 \\
(0.173) \\
\end{array}$ & $\begin{array}{c}0.152 \\
(0.152) \\
\end{array}$ & $\begin{array}{l}0.229^{*} \\
(0.127) \\
\end{array}$ \\
\hline Micro-Firms ( 1 to 5 workers) & $\begin{array}{l}-0.121 \\
(0.160)\end{array}$ & $\begin{array}{l}-0.128 \\
(0.129)\end{array}$ & $\begin{array}{c}-0.072 \\
(0.109)\end{array}$ \\
\hline Small/Medium-Firms ( 6 to 99 workers) & $\begin{array}{c}0.085 \\
(0.070)\end{array}$ & $\begin{array}{c}0.088 \\
(0.063)\end{array}$ & $\begin{array}{c}0.066 \\
(0.055)\end{array}$ \\
\hline Large-Firms (100 plus workers) & $\begin{array}{l}0.040 \\
(0.084)\end{array}$ & $\begin{array}{l}0.007 \\
(0.071)\end{array}$ & $\begin{array}{c}0.018 \\
(0.062)\end{array}$ \\
\hline
\end{tabular}

Note: ***Indicate statistical significance at the $1 \%$ level. **For the $5 \%$ level. *For the $10 \%$ level. Standard errors are shown in parentheses. 
Table A6: Estimates of the effect of the Campaign on whether self-employed workers transition into full-time employment in 2011

\begin{tabular}{l|ccc|cccc}
\hline \hline & \multicolumn{2}{|c|}{ Non-parametric: Rectangular kernel } & \multicolumn{3}{|c}{ Non-parametric: Triangular kernel } & Polynomial \\
\hline Bandwidth & $(+/-0.10)$ & $(+/-0.15)$ & $(+/-0.21)$ & $(+/-0.10)$ & $(+/-0.15)$ & $(+/-0.21)$ & (5th order $)$ \\
\hline RD effect & 0.295 & $0.274^{*}$ & $0.197^{*}$ & 0.341 & 0.288 & $0.235^{*}$ & 0.072 \\
& $(0.210)$ & $(0.149)$ & $(0.112)$ & $(0.260)$ & $(0.181)$ & $(0.126)$ & $(0.063)$ \\
& & & & & & & \\
N & 108 & 174 & 247 & -- & -- & -- & 1148 \\
R2 & 0.042 & 0.03 & 0.03 & -- & -- & -- & 0.012 \\
\hline
\end{tabular}

Notes: ${ }^{1 .}$ The bandwidths for the non-parametric triangular kernel estimates were chosen based on the technique described in Imbens and Kalyanaraman (2009). ***Indicate statistical significance at the $1 \%$ level.

**For the $5 \%$ level. *For the $10 \%$ level. Standard errors are shown in parentheses. 
Table A7: Regression discontinuities in potential covariates

\begin{tabular}{|c|c|c|c|}
\hline \multicolumn{4}{|c|}{ Non-parametric: Triangular kernel } \\
\hline Bandwidth & $(+/-0.10)$ & $(+/-0.15)$ & $(+/-0.21)$ \\
\hline Age & $\begin{array}{c}1.474 \\
(1.056)\end{array}$ & $\begin{array}{c}0.779 \\
(0.866)\end{array}$ & $\begin{array}{c}0.671 \\
(0.769)\end{array}$ \\
\hline Gender $($ Male $=1)$ & $\begin{array}{c}0.232 * * * \\
(0.041)\end{array}$ & $\begin{array}{c}0.192 * * * \\
(0.034)\end{array}$ & $\begin{array}{c}-0.167 * * * \\
(0.030)\end{array}$ \\
\hline Years of Education & $\begin{array}{c}1.252 * * * \\
(0.337)\end{array}$ & $\begin{array}{c}0.822 * * * \\
(0.280)\end{array}$ & $\begin{array}{c}0.703 * * * \\
(0.251)\end{array}$ \\
\hline Small Firm & $\begin{array}{r}-0.0286 \\
(0.038)\end{array}$ & $\begin{array}{l}-0.002 \\
(0.032)\end{array}$ & $\begin{array}{l}-0.008 \\
(0.029)\end{array}$ \\
\hline Union Membership & $\begin{array}{l}0.038^{*} \\
(0.022)\end{array}$ & $\begin{array}{c}0.013 \\
(0.017)\end{array}$ & $\begin{array}{c}0.004 \\
(0.014)\end{array}$ \\
\hline Commerce & $\begin{array}{c}0.0236 \\
(0.036)\end{array}$ & $\begin{array}{c}0.031 \\
(0.029)\end{array}$ & $\begin{array}{c}0.028 \\
(0.026)\end{array}$ \\
\hline Finance & $\begin{array}{c}0.093 * * * \\
(0.027)\end{array}$ & $\begin{array}{c}0.057 * * * \\
(0.021)\end{array}$ & $\begin{array}{c}0.053 * * * \\
(0.018)\end{array}$ \\
\hline Construction & $\begin{array}{c}-0.113 * * * \\
(0.021)\end{array}$ & $\begin{array}{c}-0.092 * * * \\
(0.017)\end{array}$ & $\begin{array}{c}-0.084 * * * \\
(0.015)\end{array}$ \\
\hline Manufacturing & $\begin{array}{c}-0.087 * * * \\
(0.027)\end{array}$ & $\begin{array}{c}-0.057 * * \\
(0.022)\end{array}$ & $\begin{array}{c}-0.040 * * \\
(0.020)\end{array}$ \\
\hline Services & $\begin{array}{c}0.220 * * * \\
(0.037)\end{array}$ & $\begin{array}{c}0.166 * * * \\
(0.030)\end{array}$ & $\begin{array}{c}0.142 * * * \\
(0.027)\end{array}$ \\
\hline Transportation & $\begin{array}{c}-0.035^{*} \\
(0.019)\end{array}$ & $\begin{array}{c}-0.046^{* *} \\
(0.016)\end{array}$ & $\begin{array}{c}-0.035^{* *} \\
(0.015)\end{array}$ \\
\hline Agriculture & $\begin{array}{c}-0.098 * * * \\
(0.037) \\
\end{array}$ & $\begin{array}{c}-0.060^{*} \\
(0.031)\end{array}$ & $\begin{array}{c}-0.061 * * \\
(0.027)\end{array}$ \\
\hline $\begin{array}{l}\text { Notes: The bandwic } \\
\text { were chosen base } \\
\text { Kalyanaraman }(200 \\
* * \text { For the } 5 \% \text { leve } \\
\text { parentheses. }\end{array}$ & $\begin{array}{l}\text {-parametric } \\
\text { chnique d } \\
\text { statistical s } \\
\text { o level. Sta }\end{array}$ & $\begin{array}{l}\text { triangular } \mathrm{k} \\
\text { scribed in } \\
\text { snificance a } \\
\text { dard errors }\end{array}$ & $\begin{array}{l}\text { hel estimates } \\
\text { Imbens and } \\
\text { he } 1 \% \text { level } \\
\text { re shown ir }\end{array}$ \\
\hline
\end{tabular}

